\title{
Geostatic modeling of the clastic reservoir: a case study the Late Cenomanian Abu Roash G Member, Hamra Field, Abu Gharadig Basin, Western Desert, Egypt
}

\author{
M. F. Abu-Hashish ${ }^{1}$ (D) M. M. Abuelhassan ${ }^{1} \cdot$ Gamal Elsayed $^{2}$
}

Received: 10 July 2021 / Accepted: 21 December 2021 / Published online: 13 January 2022

(c) The Author(s) 2022

\begin{abstract}
Recent advances in computer sciences have resulted in a significant improvement in reservoir modeling, which is an important stage in studying and comprehending reservoir geometry and properties. It enables the collection of various types of activities such as seismic, geological, and geophysical aspects in a single container to facilitate the characterization of reservoir continuity and homogeneity. The main goal of this work is to build a three-dimensional reservoir model of the Abu Roash G reservoir in the Hamra oil field with enough detail to represent both vertical and lateral reservoir heterogeneity at the well, multi-well, and field scales. The Late Cenomanian Abu Roash G Member is the main reservoir in the Hamra oil field. It is composed mainly of shale, carbonate and some streaks of sandstone, these streaks are shaly in some parts. Conducting the 3D geostatic model begins with the interpretation of seismic data to detect reflectors and horizons, as well as fault picking to explain the structural framework and frequently delineate the container style with proposed limitations to construct the structural model. The lithology and physical properties of Abu Roash G reservoir rock, including total and effective porosity and fluid saturation, were determined using well log data from four wells in the Hamra field. The constructed 3D geological model of the Abu Roash G has showed that the petrophysical parameters are controlled by the facies distribution and structure elements, whereas properties are the central part to the northern side of the deltaic environment than the other sides of the same environment. The model will be useful in displaying the reservoir community and indicating prospective zones for enhancing the dynamic model to improve the behavior of the flow unit productivity, as well as, section of the best sites for the future drilling.
\end{abstract}

Keywords Geostatic model $\cdot$ Seismic data interpretation $\cdot$ Property modeling

\section{Introduction}

The occurrence of hydrocarbons in the Egyptian western desert is closely related to the area's tectonic activities and stratigraphic history, which has created a series of reservoirs and seals. The majority of fields in the northern western desert are related to structures formed during the Late Cretaceous-Eocene period (Abu El Naga 1984). The majority of Egypt's sedimentary basins are in the northern Western Desert, such as the Matruh-Shushan, North Meleiha,

M. F. Abu-Hashish

mfarouk64@gmail.com

1 Geology Department, Faculty of Science, Menoufiya University, Al Minufiyah, Egypt

2 Qarun Petroleum Company (QPC), Cairo, Egypt
Alamein, Abu Gharadig, Gindi, and Beni Suef basins. The Abu Gharadig Basin is nearly the largest basin in the northern Western Desert, with numerous oil and gas fields in its depo-center and troughs, including the Abu Gharadig field, North Abu Gharadig field, Badr El-Din (BED) lease, GPT field, Wadi field (WD 33), Asala platform, Diyur field, and Karama lease, Raham lease, and Hamra oil field (Fig. 1). The current study aims to combine the various data available for better understanding the subsurface system and the character of the Late Cretaceous reservoirs in the Hamra oil field. As well as, to build a 3D reservoir model with enough detail to represent vertical and lateral heterogeneity at the well, multi-well, and field scales, which could be used as a tool for optimum reservoir management. One of the many crucial components of the three-dimensional reservoir modeling is to provide one or more options. Geostatistical approaches play a vital role in this process. 3D numerical models are 
Fig. 1 Location Map of Hamra oil field in East Bahariya Concession

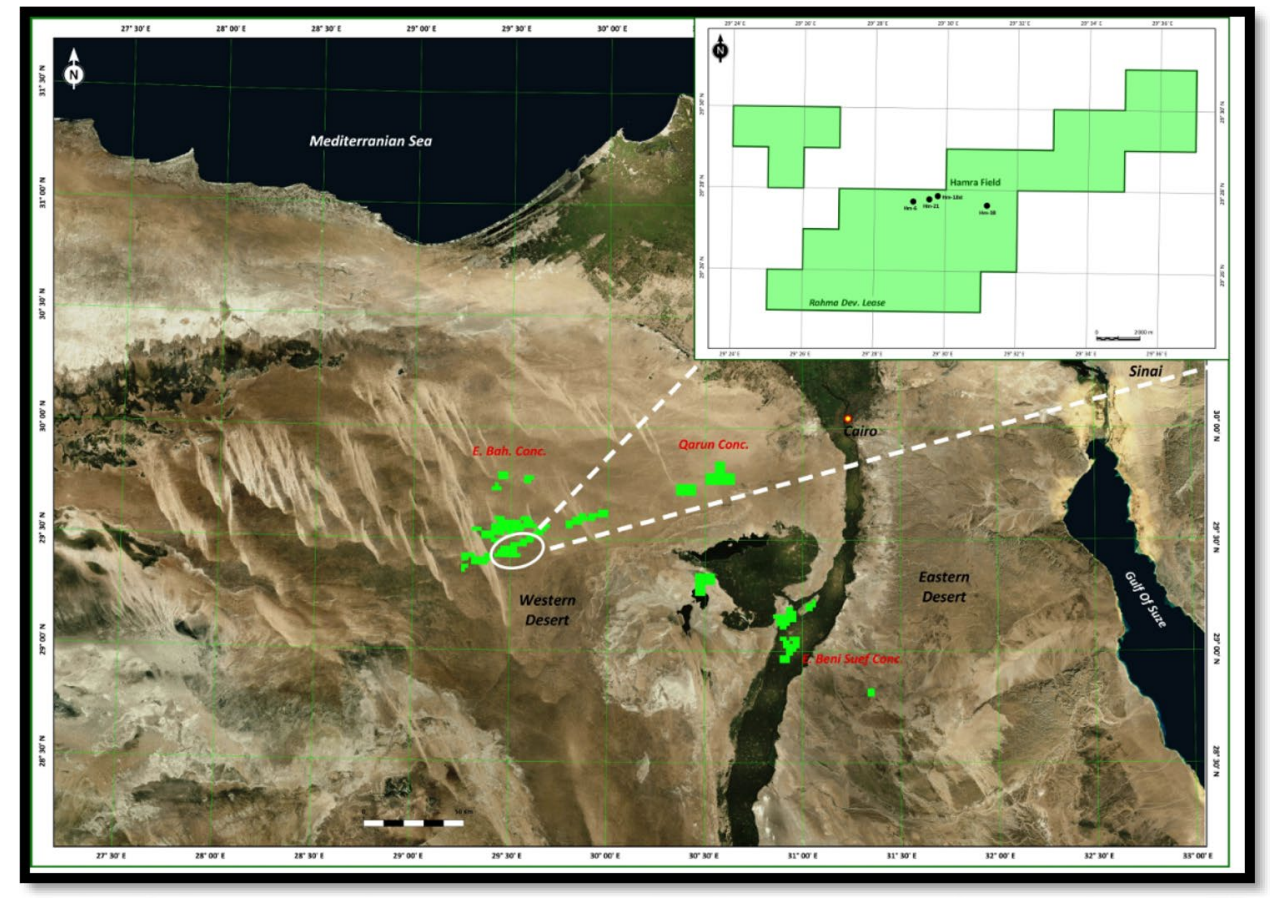

used to estimate the main reservoir characteristics of the subsurface of the research region that help in the study's aims to represent such geological, geophysical, and reservoir engineering concerns. These numerical models are used to predict production, evaluate critical reservoir features such as original oil in situ (OOIP), and provide uncertainty statements as needed (Caers 2005). Reservoir modeling may be split into two types; static and dynamic. Abu Gharadig was subjected to many works discussing its tectonic, stratigraphy, geological history and hydrocarbon partialities; among of them Awad (1984), Schlumberger (1984), Bayoumi and Lotfy (1989), Bayoumi (1996), El Diasty (2014), El-Sherbiny (2002), Hendy et al. (1992), Mahmoud et al. (2016), Shahin et al. (1986), Kamel (2017) and Mahmedd (2018) and others.

\section{Materials and methods}

The available data for this work include twenty 3D Seismic lines (13 cross-line, 7 in-line) and complete set of well $\log$ f for four wells. The following techniques were used to achieve the main goal of the study (Fig. 2):

- Seismic interpretation by picking on seismic data, there are two modules of interpretation; Horizon interpretation, which is carried out on the horizons of interest, and Fault interpretation for the interesting section, and then, all seismic interpretations are used for mapping surfaces, which are used to a building block for the constructed structural model, using Petrel software.

- Determination of the petrophysical characteristics of the Abu Roash G reservoir (shale volume, net pay thickness, porosity, water saturation, and hydrocarbon saturation) as well as, construction different types of maps for Abu Roash G reservoir by using Interactive Petrophysics software.

- Create facies models that would reduce exploration risk and increase the development opportunities in the Hamra Oil Field.

\section{Geologic settings}

Abu Gharadig basin, which is a major structural basin in the Western Desert, has a variety of hydrocarbon potentiality keys e.g., Upper Jurassic Khatatba Formation and Upper Cretaceous (Turonian) Abu Roash "F" Member both as source rock; Bahariya, Kharita, and Abu Roash Formations as reservoir rock; Abu Roash shale and carbonates and Khoman Fm. as seal rock. The encountered traps in this basin are varied in classification: structural, stratigraphic or combination type; geometry: elongated or rounded; and size: ranging from few square kilometers to hundreds of square kilometers with various reservoir pressure values and frequently variable production rate resulting from the variation of lithology, porosity, permeability, fluid saturation, and fluid properties. Egypt can be divided into six distinctive tectonic units; each 
Fig. 2 The Workflow applied on the study area

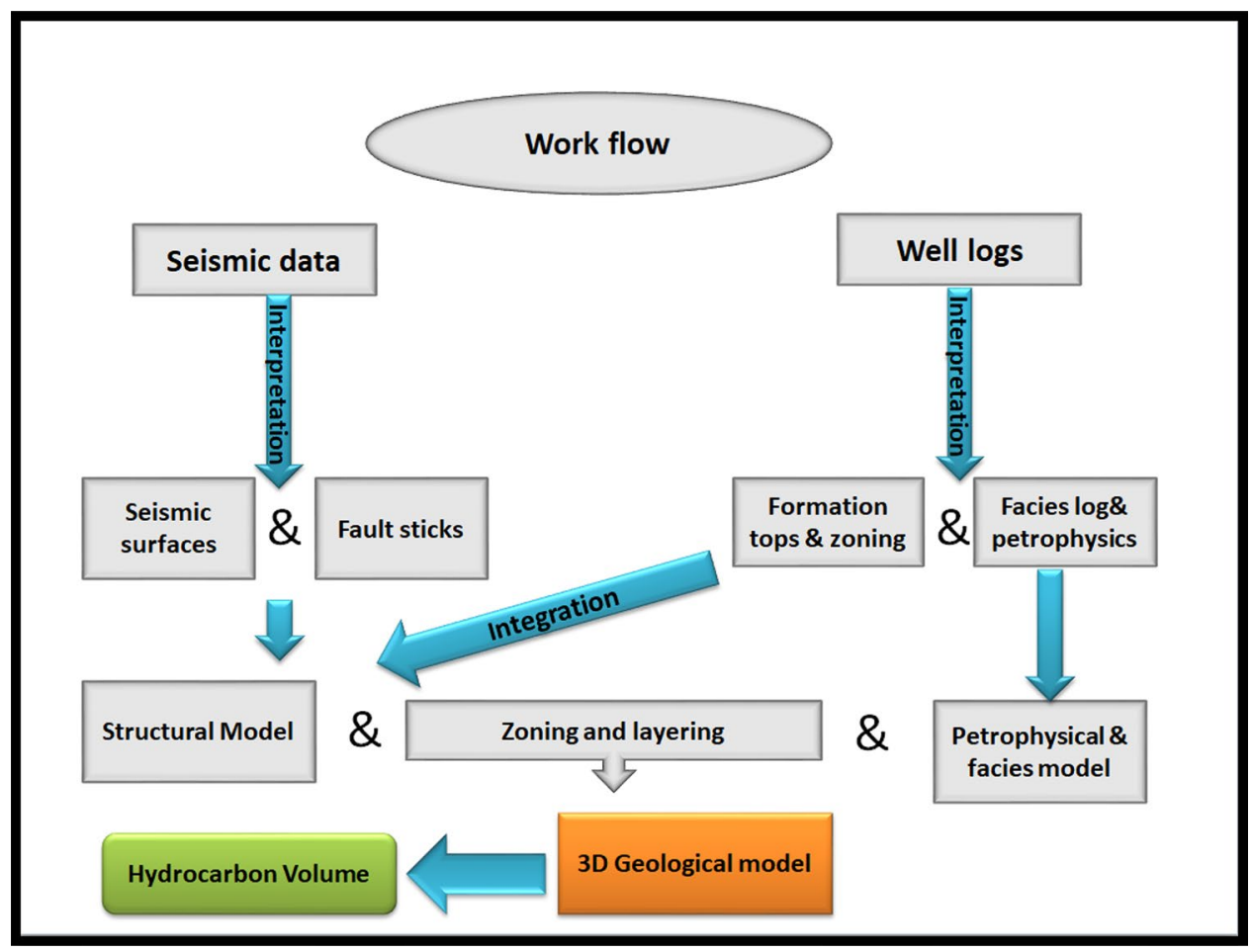

one possesses characteristic structural features and geological history. There are two major historical tectonic features that affected all over Egypt; the first one with NW-SE trending that happened during Jurassic time; namely Jurassic Trend, and the other with NE-SW trending happened during Cretaceous time and called Cretaceous Trend (Meshref et al. 1988) (Fig. 3). Abu Gharadig Basin may have begun life as a pull-apart basin between two right-lateral wrench faults, its development began during the Jurassic and Cretaceous; the tectonic activity reached a peak during the Upper Cretaceous to Eocene interval (Schlumberger 1995).

The area is highly deformation by folding and faulting activities, especially by the most pronounced structural feature "the Syrian Arc fold system" which started, with the end of the Cenomanian age, and was intensively active during Turonian-Santonian interval and was culminated with local rejuvenation during the Eocene (Abu El Ata 1988). This major system results in series of anticlines and synclines that are characterized by; Asymmetrical folding, Double plunging folds. Two major axis trends, NE-SW, and ENE-WSW, Reverse faulting parallel to fold axes, and Normal faulting perpendicular and oblique to axes. Shear movement along wrench faults that trend generally ENE (Abd El Aziz et al. 1998). The East Bahariya concessionwhere the study area exists-is an eastern extension of the Abu Gharadig basin (Wescott et al. 2011). The eastern side of Abu Gharadig basin inclusive of the study area is defined on the south by the NE trending Asala Ridge, part of the regional Kattaniya Ridge, and to the north by a

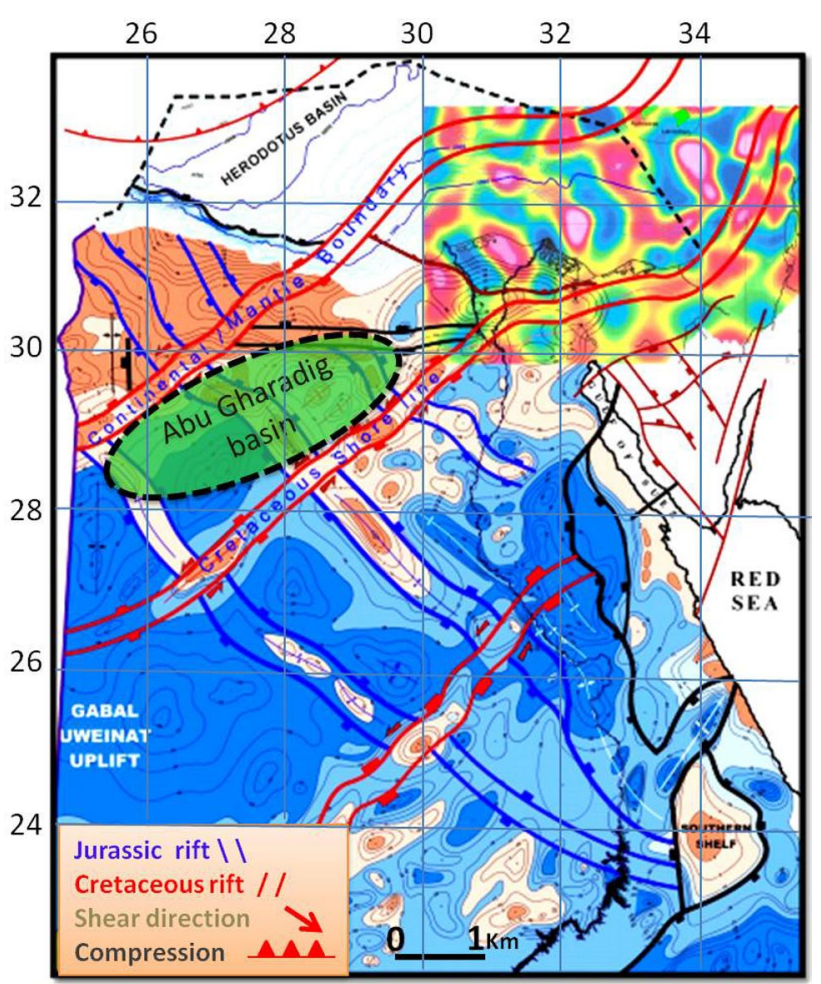

Fig. 3 Tectonic framework of Egypt (modified after Meshref, 1988)

series of large-displacement, south-dipping normal faults define the northern edge of the Abu Gharadig basin as far west as the Badr El-Din fields (Fathi 2010). This area 


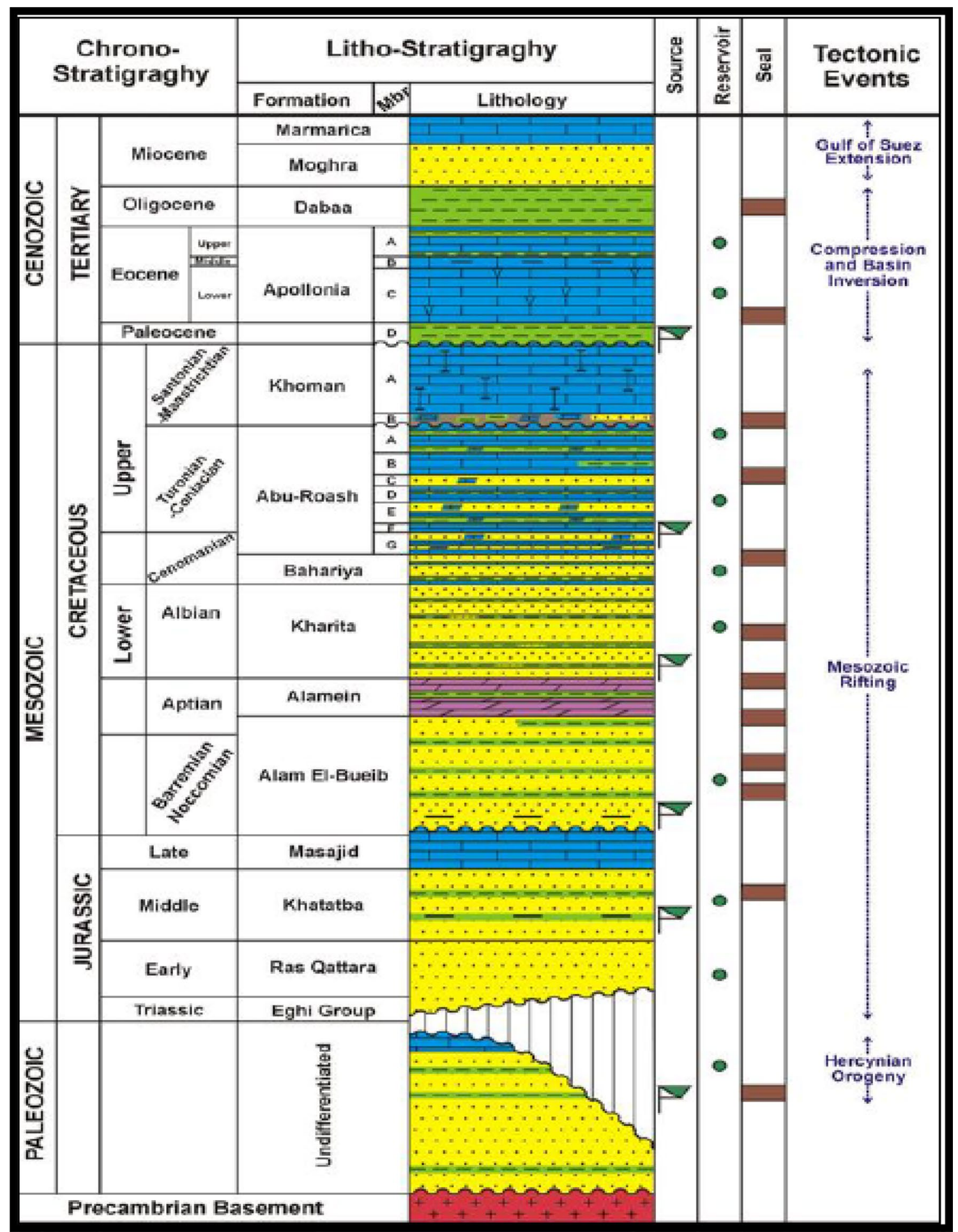

Fig. 4 Generalized stratigraphic column of the north Western Desert of Egypt. (After, Moustafa et al. 2003)

is structurally complex having undergone several periods of extension in the Jurassic and Cretaceous and at least one period of Late Cretaceous-Tertiary compression. Trap sizes are relatively small but in aggregate constitute a valuable resource (Pivnik et al. 2007). Especially the area of study is affected by this compressional sense. 


\section{Subsurface stratigraphy}

Three stratigraphic cycles were detected in the Abu Gharadig basin ranges, in age, from Cambrian to Holocene time, varying in lithology (Fig. 4), with thickness reaches 13,123 ft. (4 km) (Said 1962) from base to top as: the Clastic dominated unit (Cambrian-Early Cretaceous), The Carbonate-dominated cycle (Late Cretaceous-Middle Eocene) and The Clastic-Carbonate cycle (Late Eocene-Holocene). The stratigraphic succession of the Abu Gharadig basin encountered multiple source rocks, including Khatatba, Alam El Bueib, Alamein formations, and the Abu Roash F Member, while the reservoir rock varies in lithology and age, including Khatatba sand, Alam El Bueib, Alamein, Kharita, Bahariya formations, and the Abu Roash C, E, and G members. Several rock units play an important role in sealing the hydrocarbon and keeping it in reservoirs throughout the stratigraphic column, including Khatatba shale, Alamein dolomite, Bahariya shale streaks, Abu Roash G shale and carbonates, Abu Roash F carbonate, Abu Roash D and B carbonates, Khoman chalk, and Apollonia carbonate. As seen in the Abu Gharadig Basin's generalized stratigraphic column, there is a gap between Paleozoic and Jurassic formations; this is because no Triassic sediments are found above the Paleozoic in this area, which could indicate that this area was folded above sea level at the end of the Paleozoic. During the lower Cretaceous (Aptian-Albian) period, the folding continued or was renewed (Said 1962). Locally in the study area, the entire sections penetrated by Hamra wells were reflected as part of the global stratigraphic column of East Bahariya. As an example, the lithological section of Hamra Field is indicated in Fig. 5. The main reservoir in the study area is the Abu Roash G Member, which is only represented in its lower and middle sections, and the upper part is missing. There is no discernible thickness change in the Abu Roash $\mathrm{G}$ reservoir or any adjacent zones among Hamra wells (Figs. 6,7), indicating a very stable structural status during deposition, resulting in steady deposition conditions and. As a result, the gross thickness of Abu Roash G reveals a symmetrical appearance (Fig. 8).

\section{Seismic data interpretation}

Twenty seismic lines were employed in this work (Fig. 9) to build the 3D structural model and find new possibilities locations for drilling developmental wells in the Hamra field, which is particularly sensitive to the velocity regime in areas of complicated geology (stratigraphically and structurally). Starting with the correlation of major geological structures to seismic reflectors, then tracing the reflectors within a given seismic line, and finally from line to line at tie points, which necessitates careful phase correlation of the events to construct seismic sections that provide information about structural geometry in a particular direction and allow viewing a $2 \mathrm{D}$ profile of the ear. The information obtained from the seismic section provides a general idea of the geological structure. Some interpreted seismic sections are chosen to demonstrate the selection of horizons and structural features in the study area. The interpretation is based on the discovery of seven reflectors: Upper Bahariya, Middle Abu Roash "G" Member, Abu Roash "F", "C", and "A" Members, Khoman Formations, and Apollonia Formations (Abdelrheim 2018).

The seismic sections in the Hamra field reveal NW-SE trending minor normal faults (F1, F2, F3, and F5) and one $\mathrm{E}-\mathrm{W}$ direction major normal fault (F4). The main normal fault in the Hamra field (F4) hits members from above Abu Roash "A" to below Upper Bahariya Formation, forming traps on the up thrown side. Members above Abu Roash "A" to below Upper Bahariya Formation were hit by F1, members above Abu Roash " $\mathrm{C}$ " to below Upper Bahariya Formation were hit by F2, and members from Abu Roash "F" to below Upper Bahariya Formation were hit by F3. Members above Abu Roash "A" and below Abu Roash "F" were affected by the F5 manor normal fault. The Khoman Formation is thicker on the down-thrown side, indicating a considerable accommodation area on the normal fault's down-thrown side. At the time of the Khoman Formation's deposition. The thickness of the Abu Roash "A" Member varies laterally, with the down thrown side appearing thicker, indicating a large accommodation space on the down thrown side of the major normal fault (F3), indicating that the major normal fault (F3) was a syn-depositional fault at the time of deposition of the Abu Roash A Member (Fig. 10a, b).

\section{Structural modeling}

The structural model is the first step to create the reservoir modeling, it based on the seismic interpretation and formation top derived from the well logs to generate the seismic surfaces. 3D structural model is made of geological horizons and faults honoring available observation data, these interpreted surfaces should fit the raw input data within an acceptable range depending upon data precision and resolution (Cosentino 2001). The input data consist of the formation top of the Middle Abu Roash "G" Member depth surfaces, the interpreted fault sticks, detailed correlation in the modeling zone. The modeling passes through different steps as fault modeling which were modeled mainly from the input fault sticks and fault cut well tops that were converted to pillars then extended and cut to the previously made surfaces of Middle Abo Roash " $G$ " from the seismic

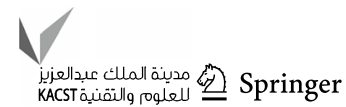


Fig. 5 Lithological section in Hamra field

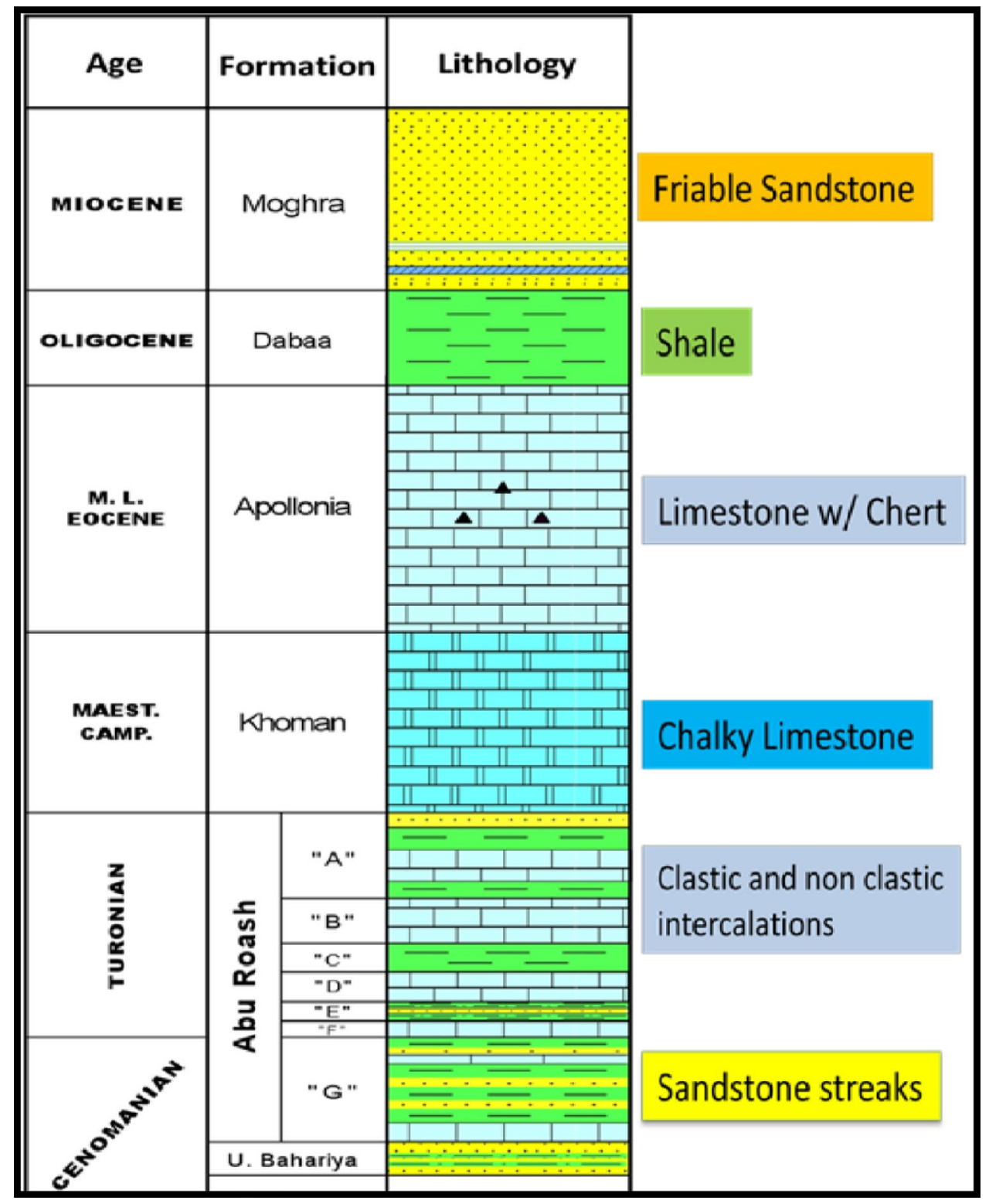

interpretation step. The process was used to create structurally corrected fault representations, fitting seismic horizons in the 3D (Fig. 11). Pillar Gridding is the next stage of structural modeling, which works on making the skeleton framework as a 2D grid mesh defined by column and rows, extended into the third dimension by the fault pillars. Pillar gridding is a way of sorting $\mathrm{X}, \mathrm{Y}$ and $\mathrm{Z}$ or I, J and $\mathrm{K}$ locations to describe a surface that was used to generate a $3 \mathrm{D}$ framework. A 3D grid divided the space up into cells within which it assumes materials were essentially the same the areal dimension of the grid cells was optimized at $50 \times 50 \mathrm{~m}$ $(164 \times 164 \mathrm{ft}$. $)$. The grid was oriented in I-trend parallel to East-West main fault, and oriented in J-trend parallel to North-South direction which perpendicular to the I-trend (Fig. 12). Horizon modeling, once the fault model network and gridding are built the Middle Abu Roash "G" Member horizons are constructed by make horizon processes, which take the main input from the 3D interpretation and well tops. Thus horizons inserted into the 3D grid as the first step in stratigraphic subdivision of the model (Fig. 13). Making Zones After Making Horizons Stage finished we can construct other zones as (Abu Roash "G-" "G-10 Base", "G-10 Base"-“G-20" Top, "G-20” and "G-21", "G-22” zones), and insert it into 3D grid by making zones processes, the thicknesses inserted below the major horizons to create the individual reservoir zones are calibrated by well tops. Layering, The final stage of structural model called layering its deal with zones of interest (oil-bearing zone), these zones have been subdivided into several sub-layers in order to capture the small scale vertical heterogeneity in appropriate 


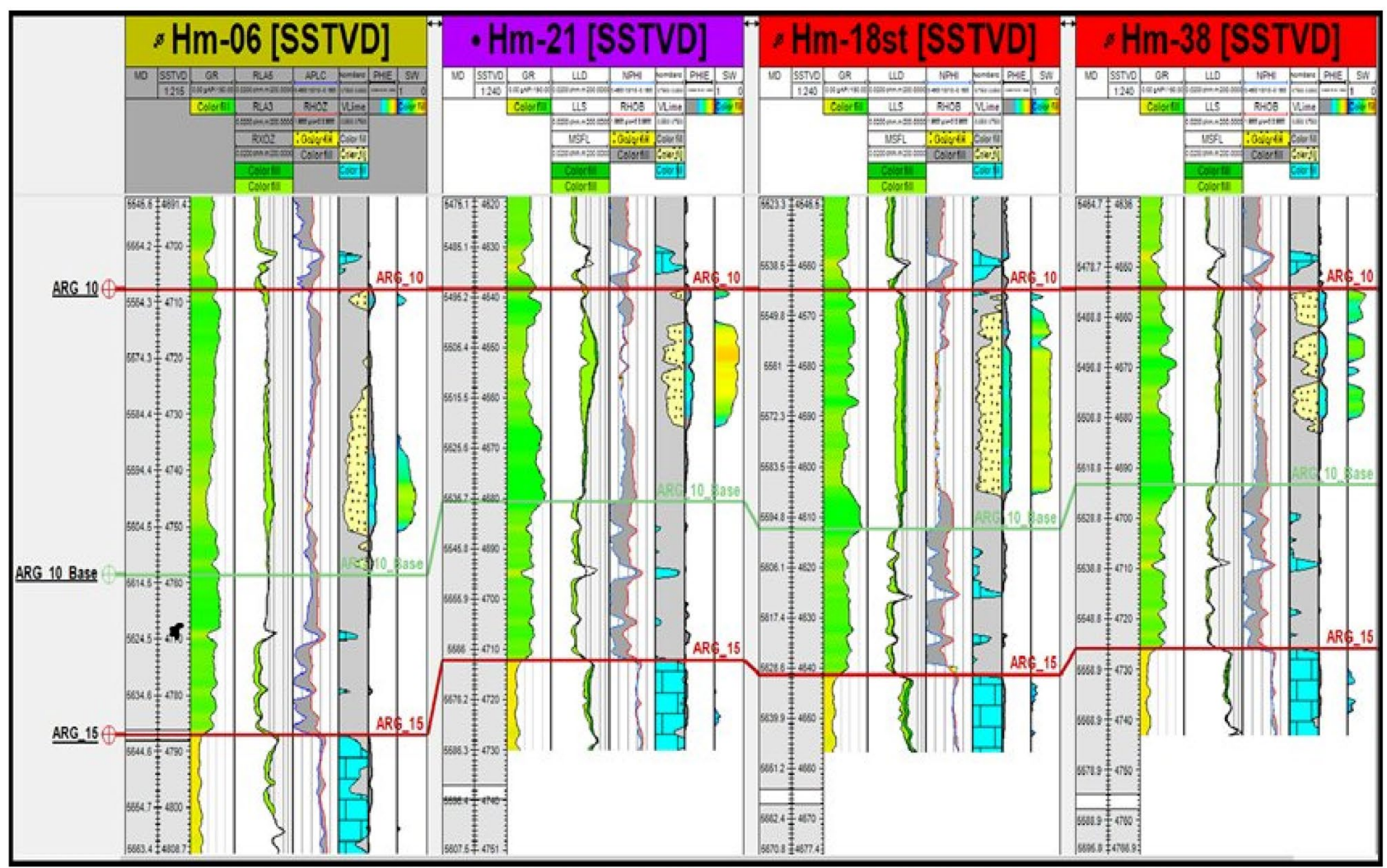

Fig. 6 Stratigraphic cross section shows the sand zone in the middle Abu Roash G in Hamra Field

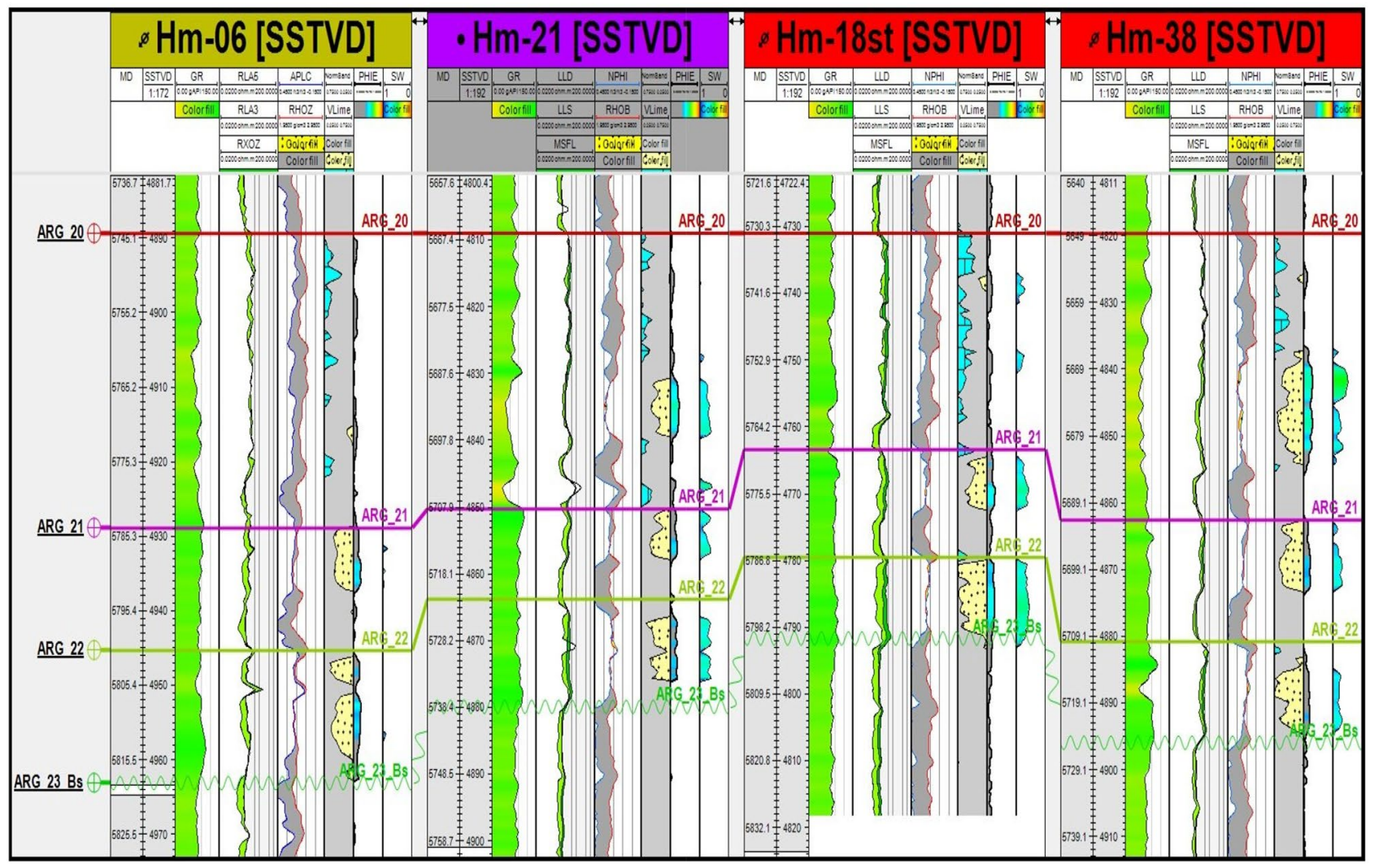

Fig. 7 Stratigraphic cross section shows the sand zones in the lower Abu Roash zone 


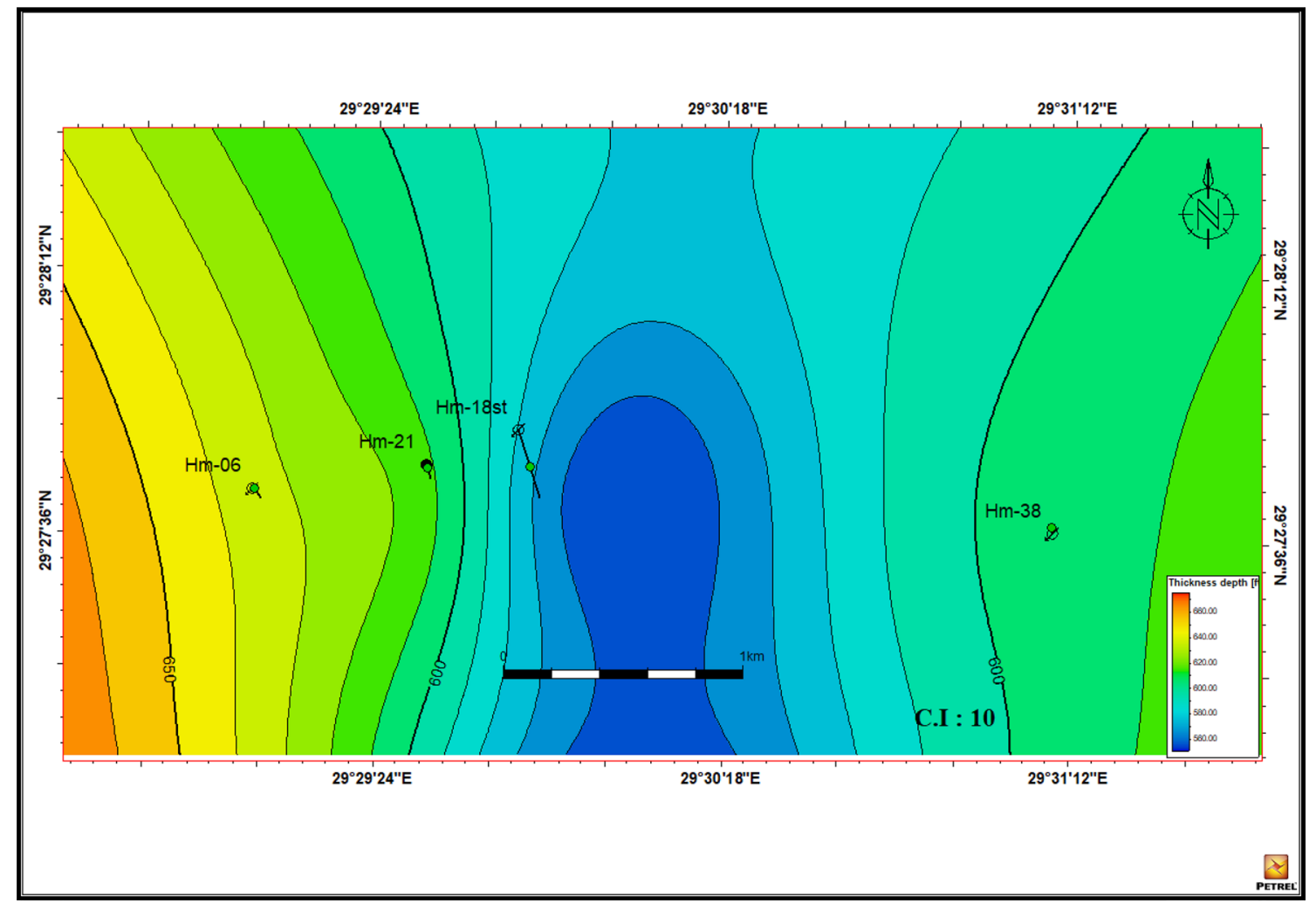

Fig. 8 Isopach map for Abu Roash G Member in Hamra field

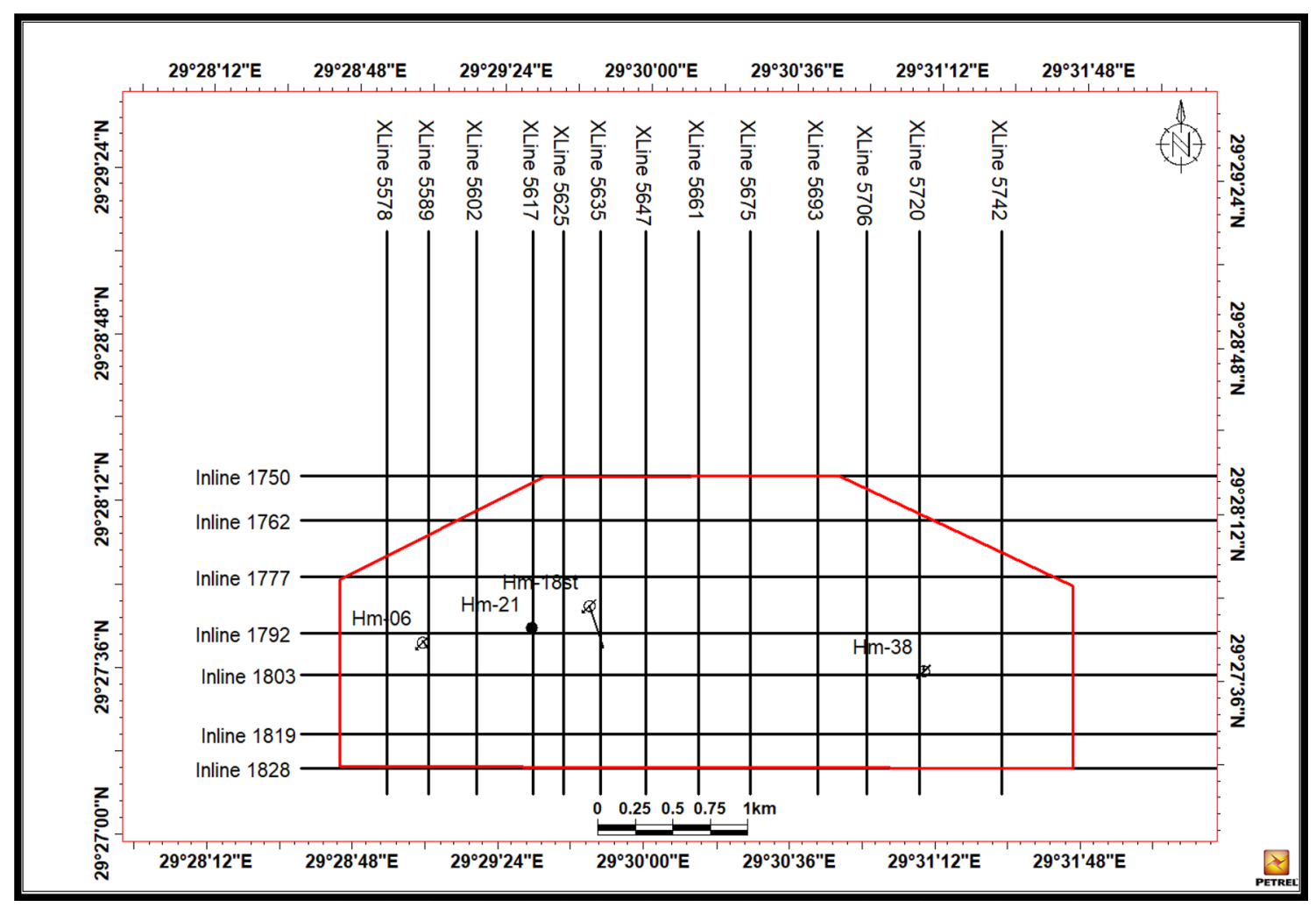

Fig. 9 Index map showing the location of 3D seismic survey of Hamra field 


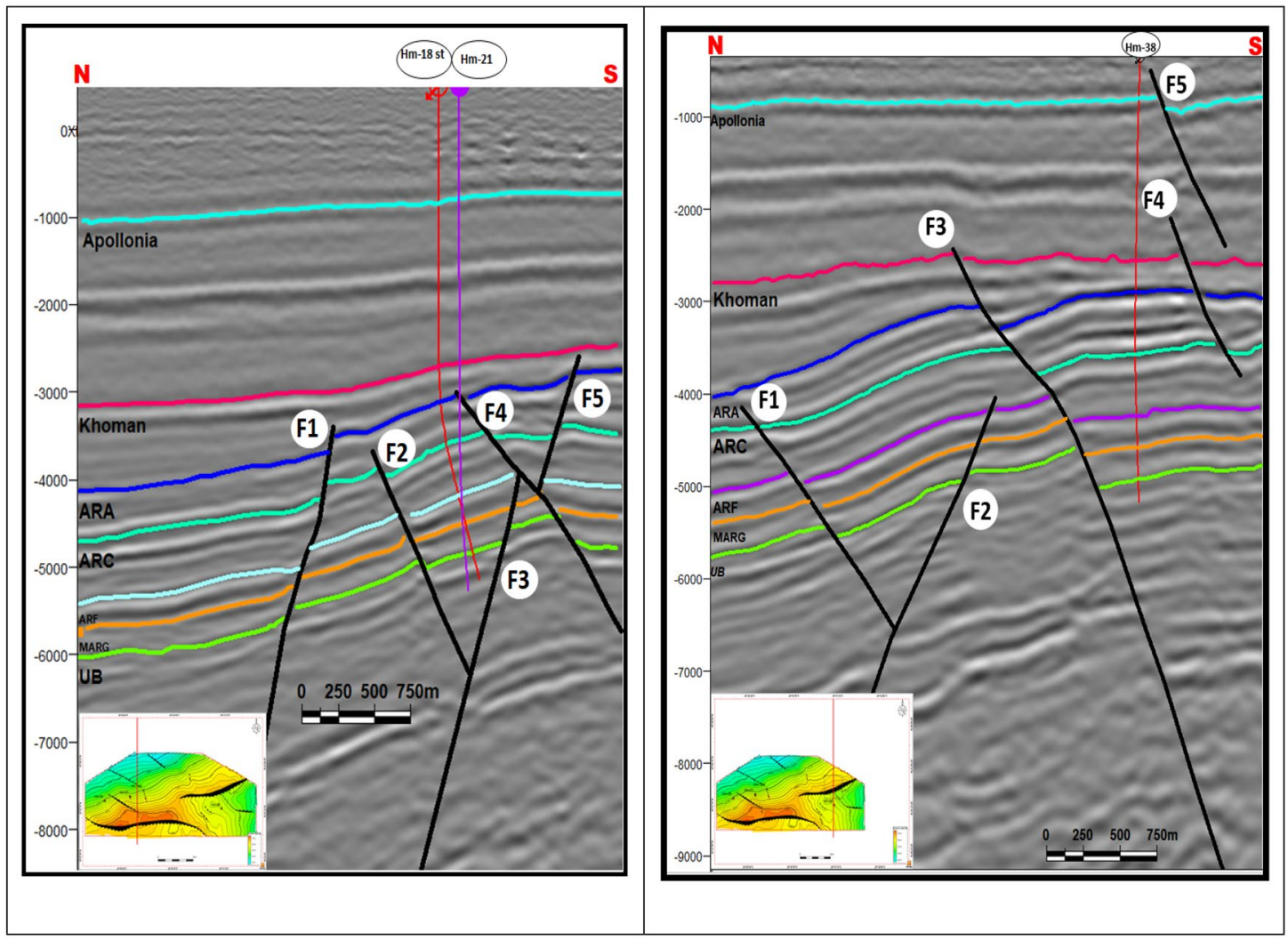

Fig. 10 a, b N-S trending seismic sections

level of details. The zones include oil-bearing layers in the model are Abu Roash "G-10", Abu Roash "G-20", "G-21", "G-22" (Fig. 14); therefore, they have been subdivided into several sub-layers in order to capture the small-scale vertical heterogeneity in appropriate level of details with respect to minimize the number of cells in the 3D model.

\section{The property model}

The aim of the property modeling was to develop a model with sufficient detail to help in locating the remaining hydrocarbons in mature producing fields, represent vertical and lateral heterogeneity at the well, multi-well, and field scale, which could be used as a tool for reservoir management and to estimate the in-place hydrocarbon volumes. This required that the model be finely layered, and have relatively small $X Y$ cell dimensions $(164 \times 164 \mathrm{ft}$., $50 \times 50 \mathrm{~m})$.

\section{Scale-up logs}

This stage dealing with grid cell population with a single facies type and a single value for each rock property. A typical model will have a representation of the facies, porosity, and water saturation properties. Before this can be done, facies and rock property values have to be assigned to the cells intersected by the wells (Shepherd 2009). There are no major changes in the values of scaled-up well logs, but a new averaging algorithm is added in order to own each piece of data by its value in the right position. Arithmetic average method gave a good results with effective porosity and water saturation reservoir properties assignment, where all the values in the cell equally. Each cell will have a unique value assigned to it because of scale-up well data. The cell assignment value was determined by averaging the values of the properties per cell. There are two average methods used in this study: the most common average method for facies properties, in which the cell selects the discrete value, which is most, represented in the log, and the arithmetic average method for effective porosity and water saturation (Fig. 15). 


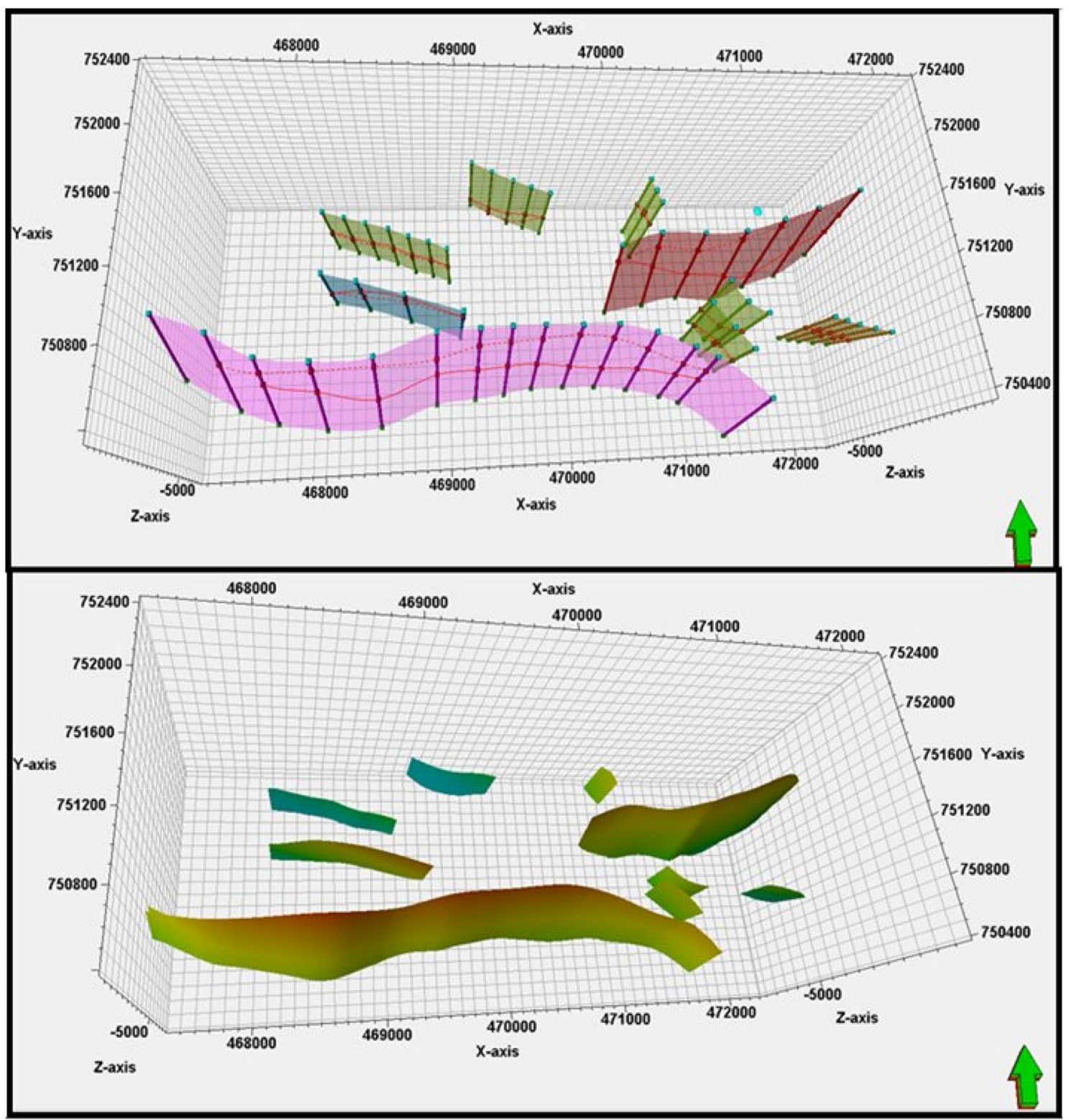

Fig. 11 3D fault modeling of El Hamra field

The results of the scale-up facies and rock properties have been checked to ensure that the main heterogeneities that influence flow are preserved after scaling-up the logs. The most important and widely used method of quality control is the histogram. The shape of the histogram distribution of the input data, interpolated data, and well logs data should be similar or semi-similar, as shown in (Fig. 16), which shows the similarity between up-scaled facies (Green column) and raw facies logs (Pink column), with reference to the code of each facies.

\section{Facies model}

The deterministic facies modeling was applied to populate all the cells in the model with lithofacies method was a suitable way in this case due to the comprehensive knowledge about the depositional reservoir patterns and reservoir architecture. The stochastic method was also used for other intervals by using the sequential indicator 


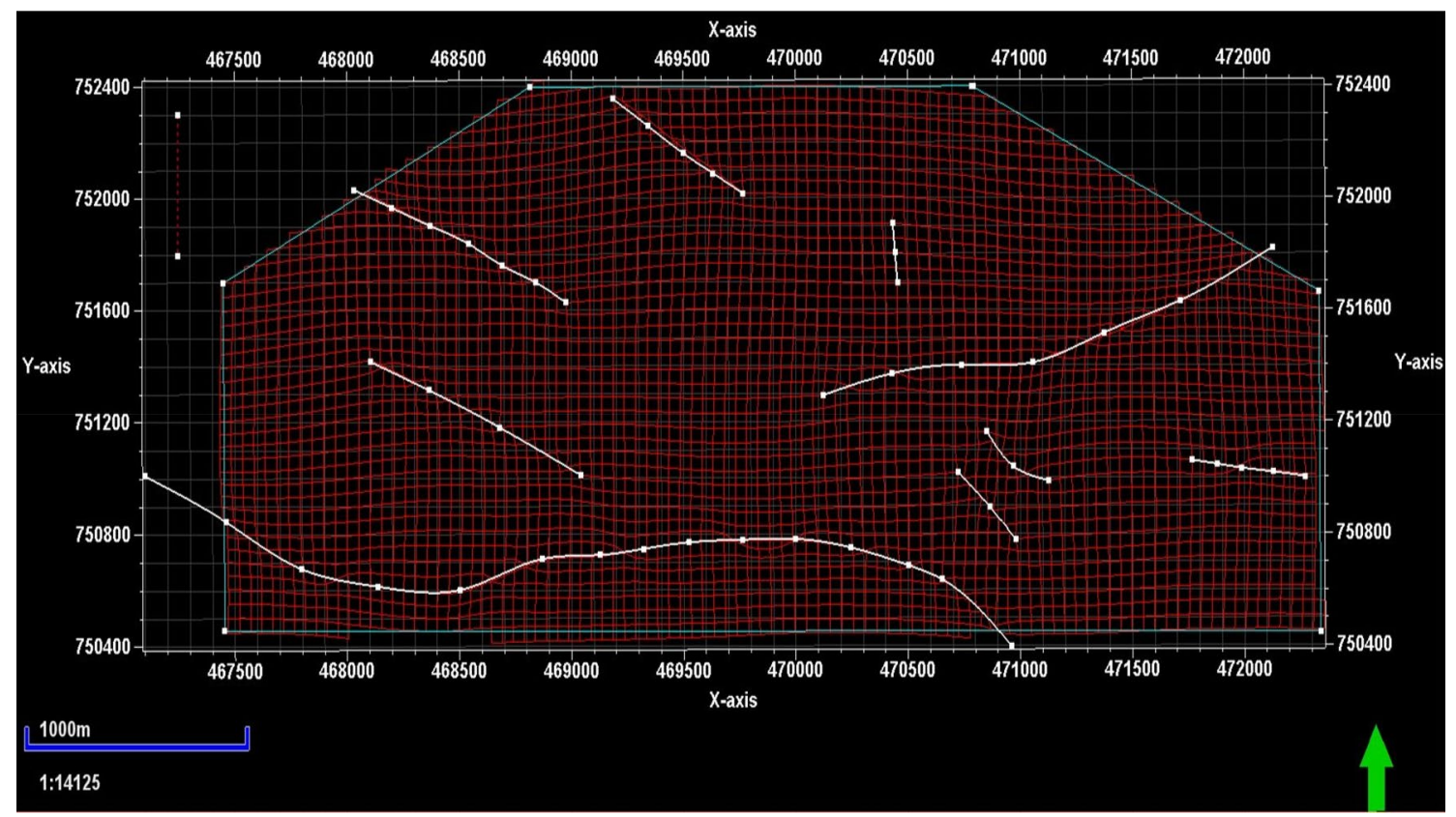

Fig. 12 2D window shows the trends of the pillar gridding

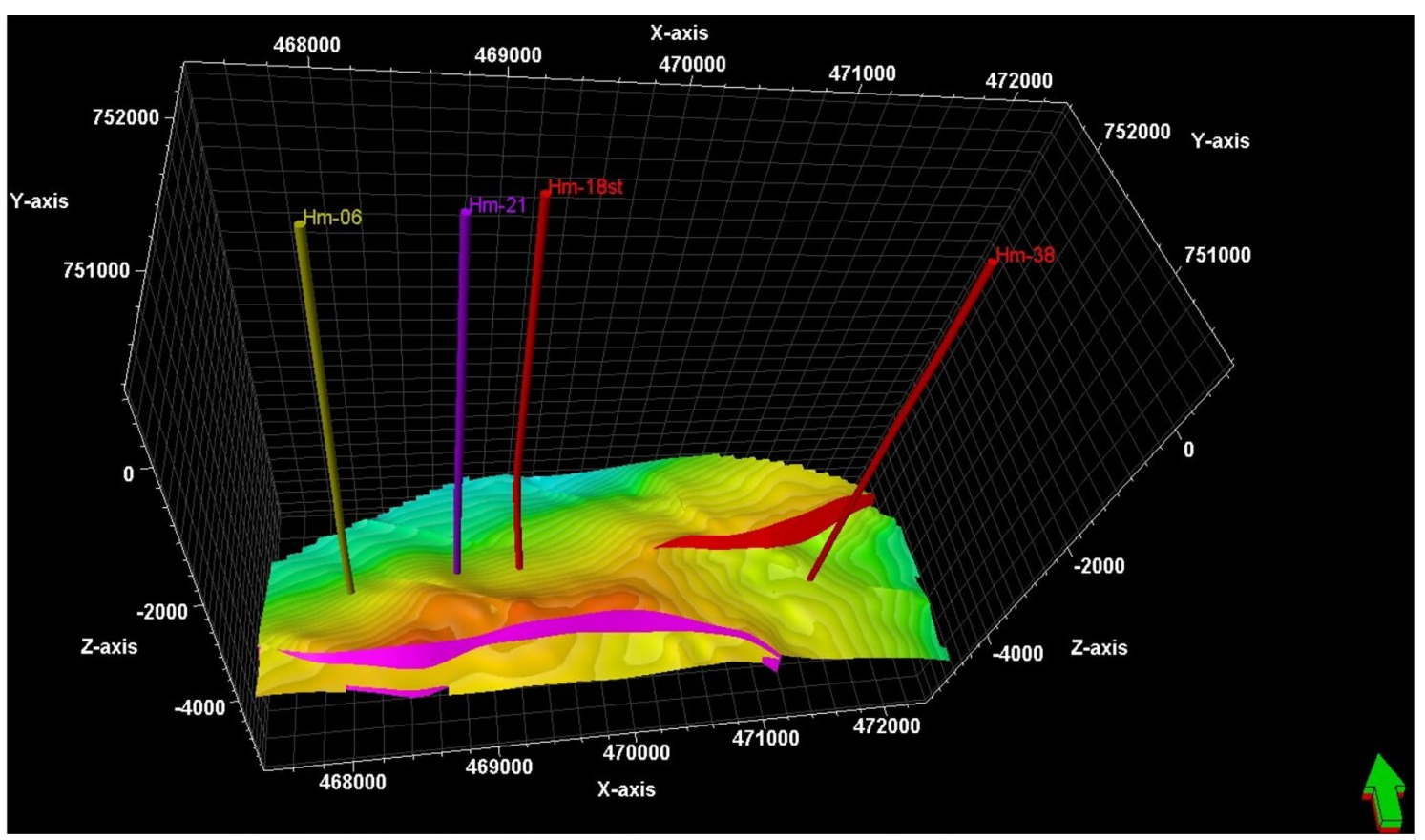

Fig. 13 3D Window shows make horizon step for the Abu Roash G Member

simulation (SIS). Sequential indicator simulation is a simulation method that is suitable for integer-coded discrete variables; rock types or lithofacies (Shepherd 2009).

This stage involves defining the spatial distribution of the rock type. In three-dimensional geological modeling, this stage is described as the populating of the reservoir model. This is the population of discrete data (lithofacies $\log$ ) into the cells of the grid that aims to understand geological processes, capture facies architecture such as reservoir connectivity \& heterogeneity, and finally to build a 3D model that describes how hydrocarbon exists and flows through the pore system in the reservoir. These facies are 


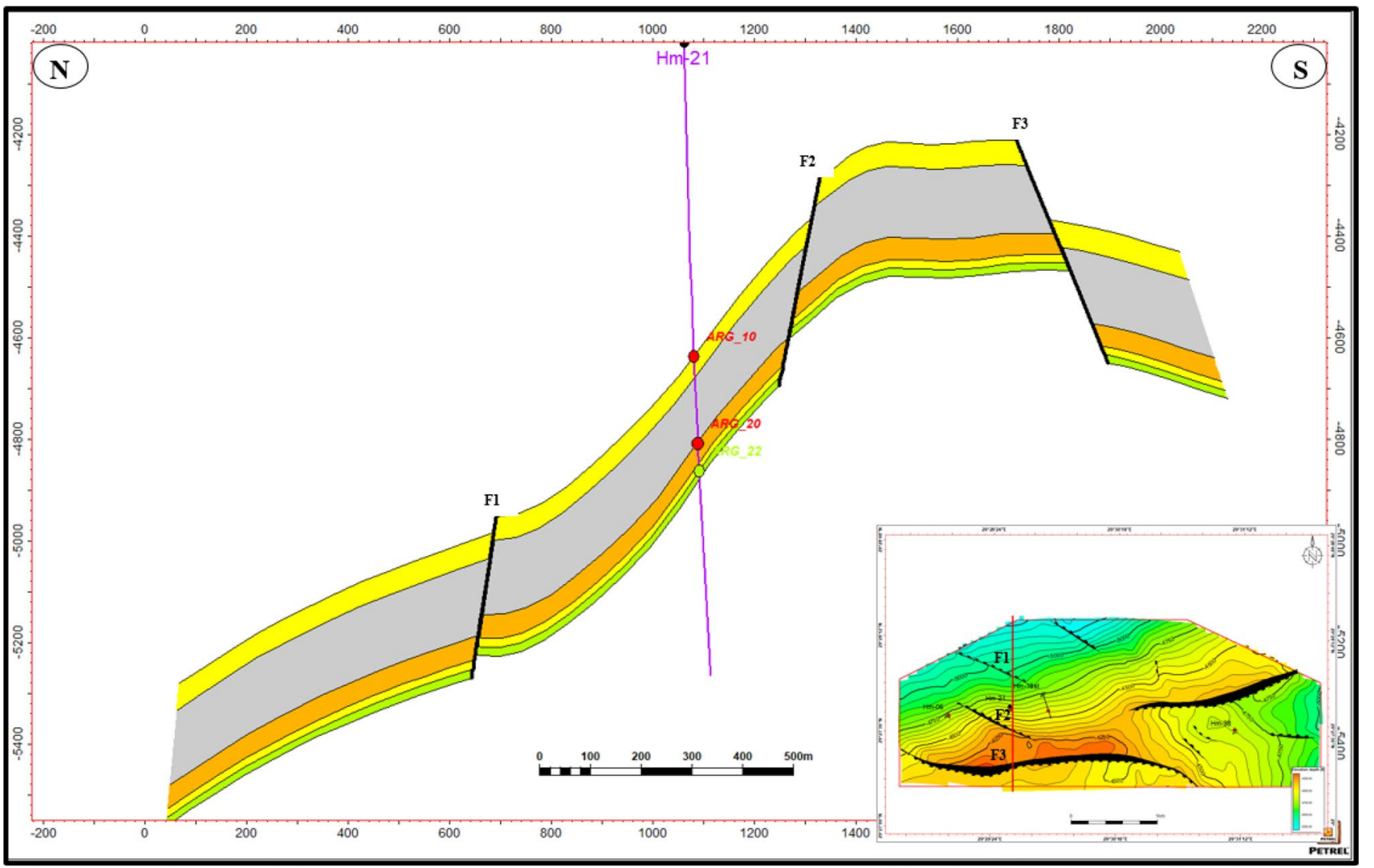

Fig. 14 Intersection window shows the vertical subdivisions "horizons and zones" of the model

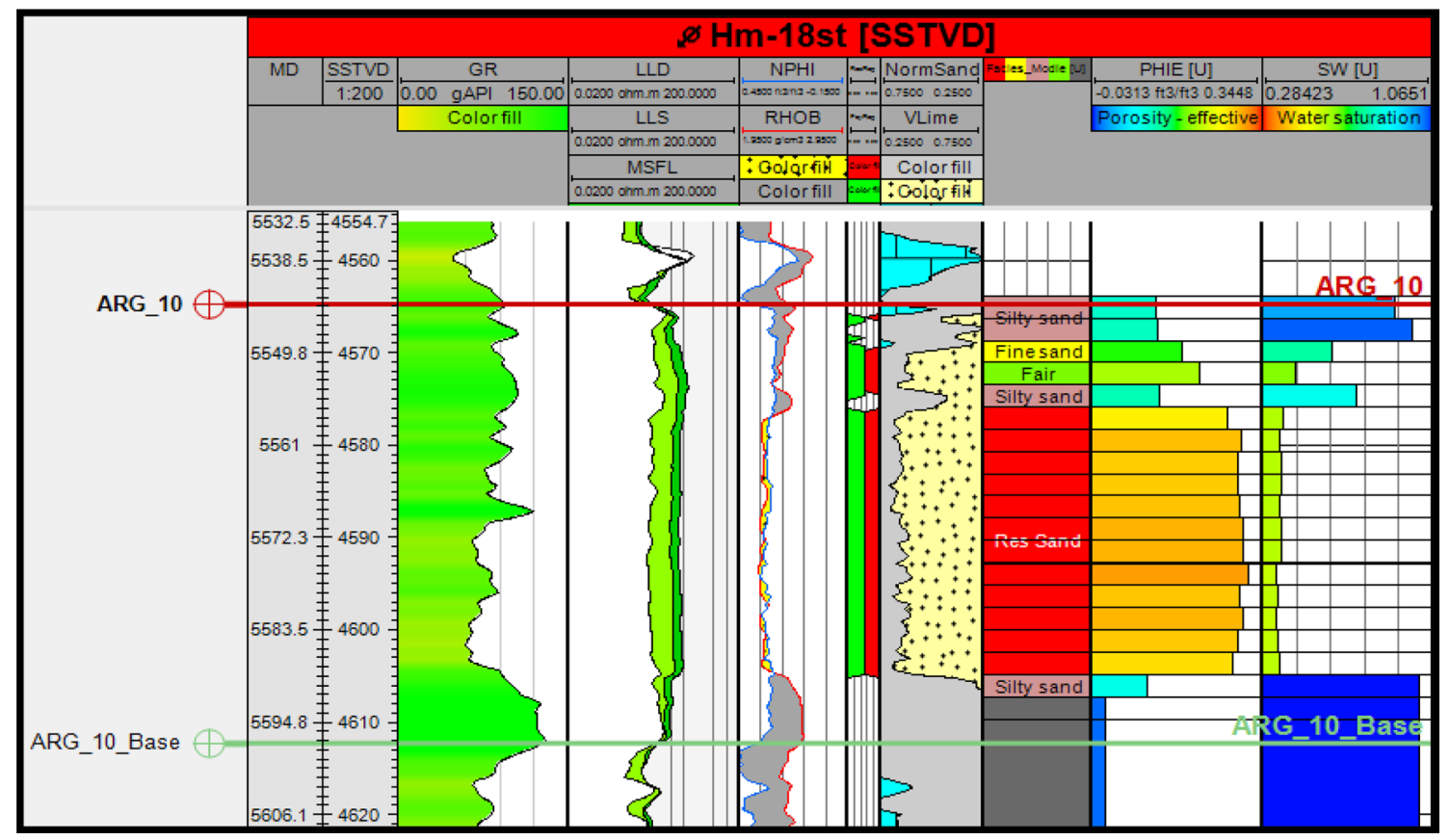

Fig. 15 Scaled up layers Middle Abu Roash "G” by log values of Facies, Effective porosity and Water saturation in Hamra-18 St well 


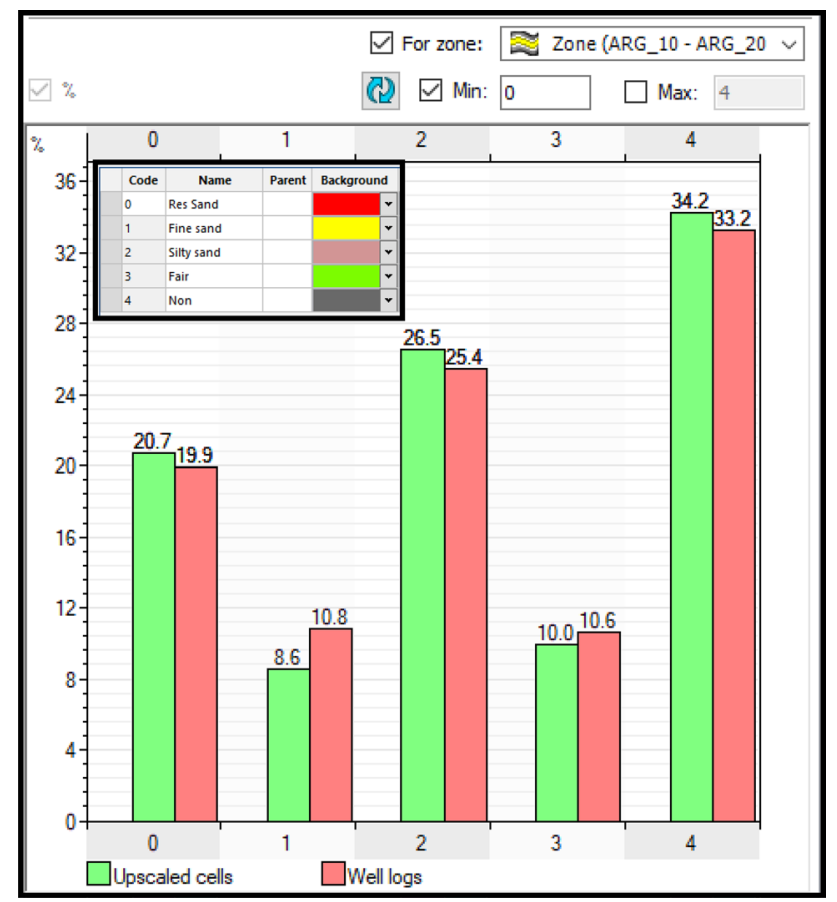

Fig. 16 Histogram shows Quality control (QC) of up-scaled facies log through Middle Abu Roash "G"

identified based on data gathered in the wells using specific, Therefore the facies were distributed as follows.

\section{Variogram}

The variogram is a measure of the variance between sample data pairs separated by a given distance in a given direction, used for modeling the spatial correlation of a data set.
It is a continuous mathematical expression used to describe the experimental variogram. It should be modeled for each facies as facies vary in correlation length with distance. How bundled these stochastically modeled pixel facies types appear is dependent on variogram range and variance (nugget). Figure 17 shows the Major direction with less anisotropy (azimuth $-60^{\circ}$ ) and minor direction with more anisotropy (azimuth $30^{\circ}$ ). Following the preparation of variogram maps, variograms for each facies should be modeled to vary in correlation length with distance. How bundled these stochastically modeled pixel facies types appear is dependent on Variogram range and variance (nugget) by data analysis process. Data Analysis is often quite experimental and thus, requires a high degree of user interaction for exploring the data, so the output will be graphical in the form of plots. Figure 18 shows the data analysis process for Abu Roash "G-10" facies. The shale non-fraction has a greater part of the probability distributions $34.2 \%$ compared to the silty sand $26.5 \%$, followed by reservoir sand zone (Res Sand) 20.7\%, Fair Sand 9.9\%, and Fine Sand 8.5\% in decreasing order of abundance.

\section{Petrophysical modeling}

Rock properties in siliciclastic rocks tend to be facies controlled (Shepherd 2009) so when modeling rock properties, it is meaningful to analyze rock properties on a facies-byfacies basis and to control the distribution of values in the model by conditioning to lithofacies. Distributions of lithofacies-dependent properties (effective porosity and water saturation) reflect the lithofacies distribution, as one would expect (Asquith and Krygowski 2004). The best porosity and permeability coincide with the main reservoir lithofacies.
Fig. 17 Selective Variogram map on Net reservoir Isopach map for Abu Roash "G-10" zone

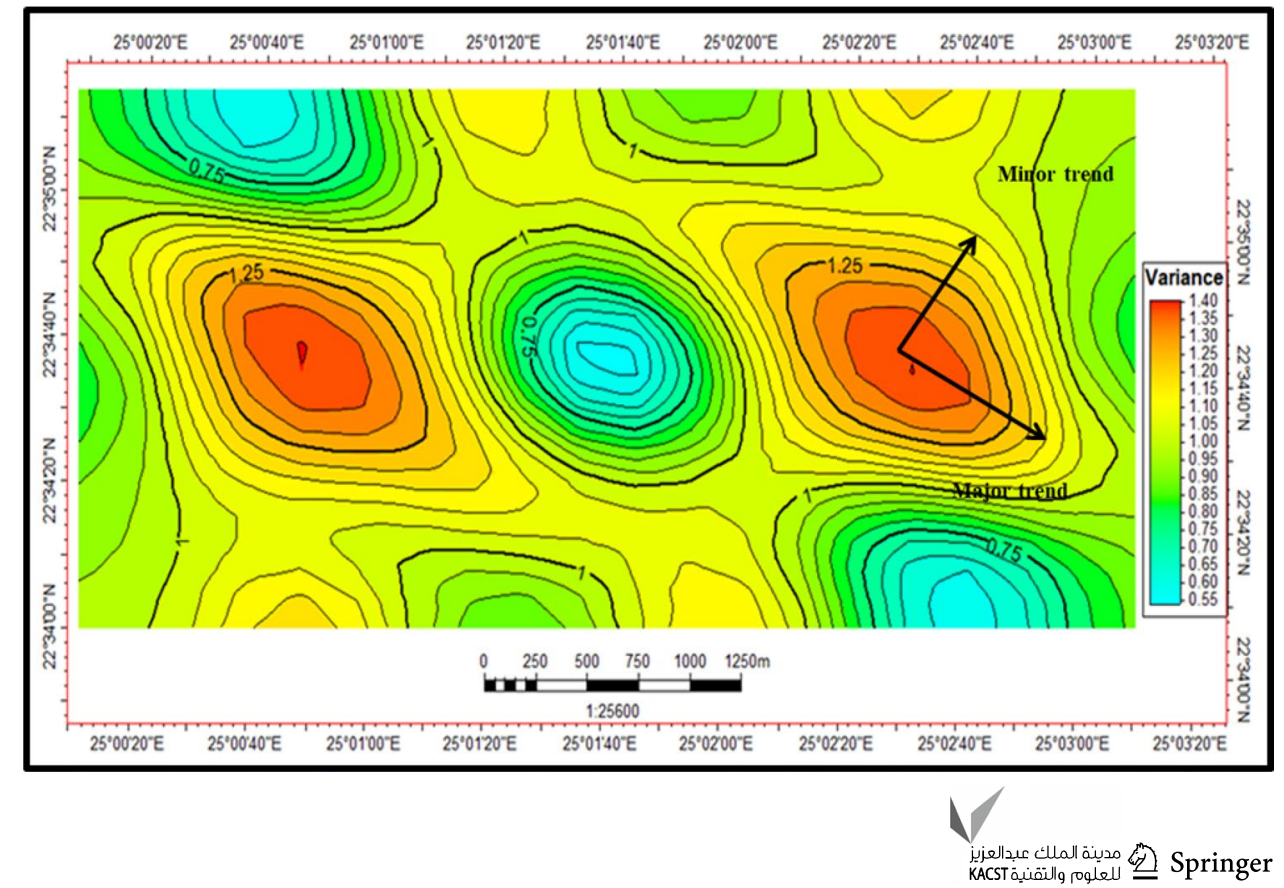




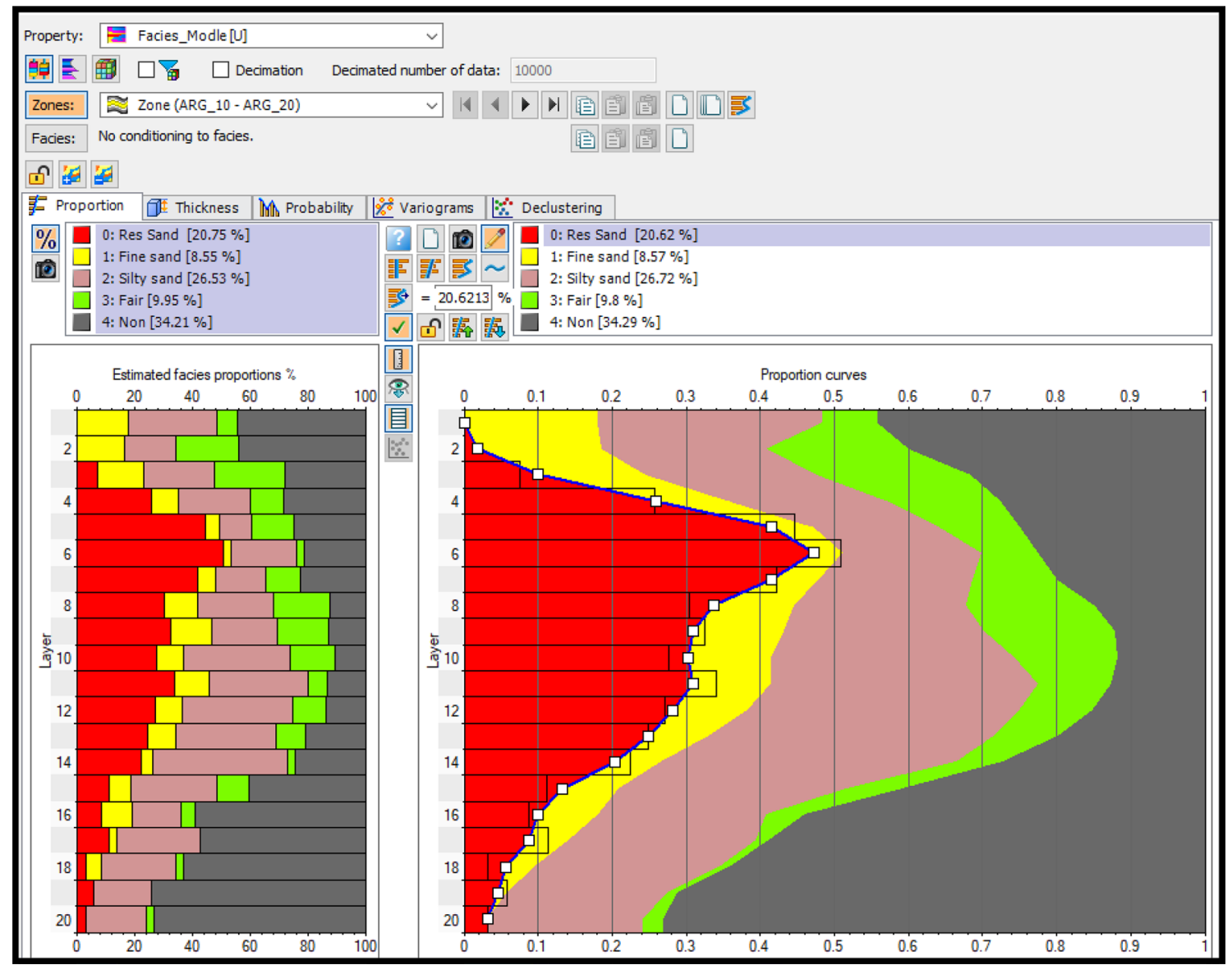

Fig. 18 Proportion facies data analysis of Abu Roash "G-10" zone

After scaling up the water saturation, effective porosity, and clay volume logs within the wells, the next stage is to populate all the cells in the model with properties using the Kriging deterministic method the scaled-up nodes of the water saturation and effective porosity distributed over the entire model. Kriging is a method for estimating the value of a surface at an un-sampled location in a statistically rigorous manner to minimize the error involved in the prediction. The estimate is made by interpolating a value between the wells where the influence of individual well values on the estimate is weighted using the variogram model (Davis 1986). In addition, we can use the data analysis process as previously mentioned, to quality control normal distribution of data controlled by each facies.

\section{Reservoir zonation}

\section{Middle Abu Roash G}

The Middle Abu Roash G sandstones were deposited in a prograding deltaic distributary environment and have a coarsening-upward profile, which corresponds to an increase in reservoir quality upwards. To capture its small-scale vertical heterogeneity (Pasley et al. 2008), it was subdivided into (20) layers. The layers below began with prodeltaic shale in some places and distributary channel in others, and in the upper layers, mouth bar sandstone was dominant in most places. The Abu Roash "G-10" layers exhibit a clear coarsening upward of facies from finest siltstone to mouth bar facies at the top, reflecting an increase in depositional energy upward that characterizes the distributary river mouth bar (Emery and Myers 1996; Cant 1992). The water saturation of the Abu Roash "G-10" zone values layer-6 ranging between (max. 100\%-min. 20\%) the low values distributed toward the structure closures. The higher water saturation values within the main closures were due to facies change from mouth bar facies to non-reservoir fine sandstone and siltstone. Abu Roash "G-10" water saturation is controlled by structure and facies, the higher water saturation values within the main closures were due to facies from mouth bar facies to inter-distributary fine sandstone and siltstone facies. The distribution of effective porosity shows 


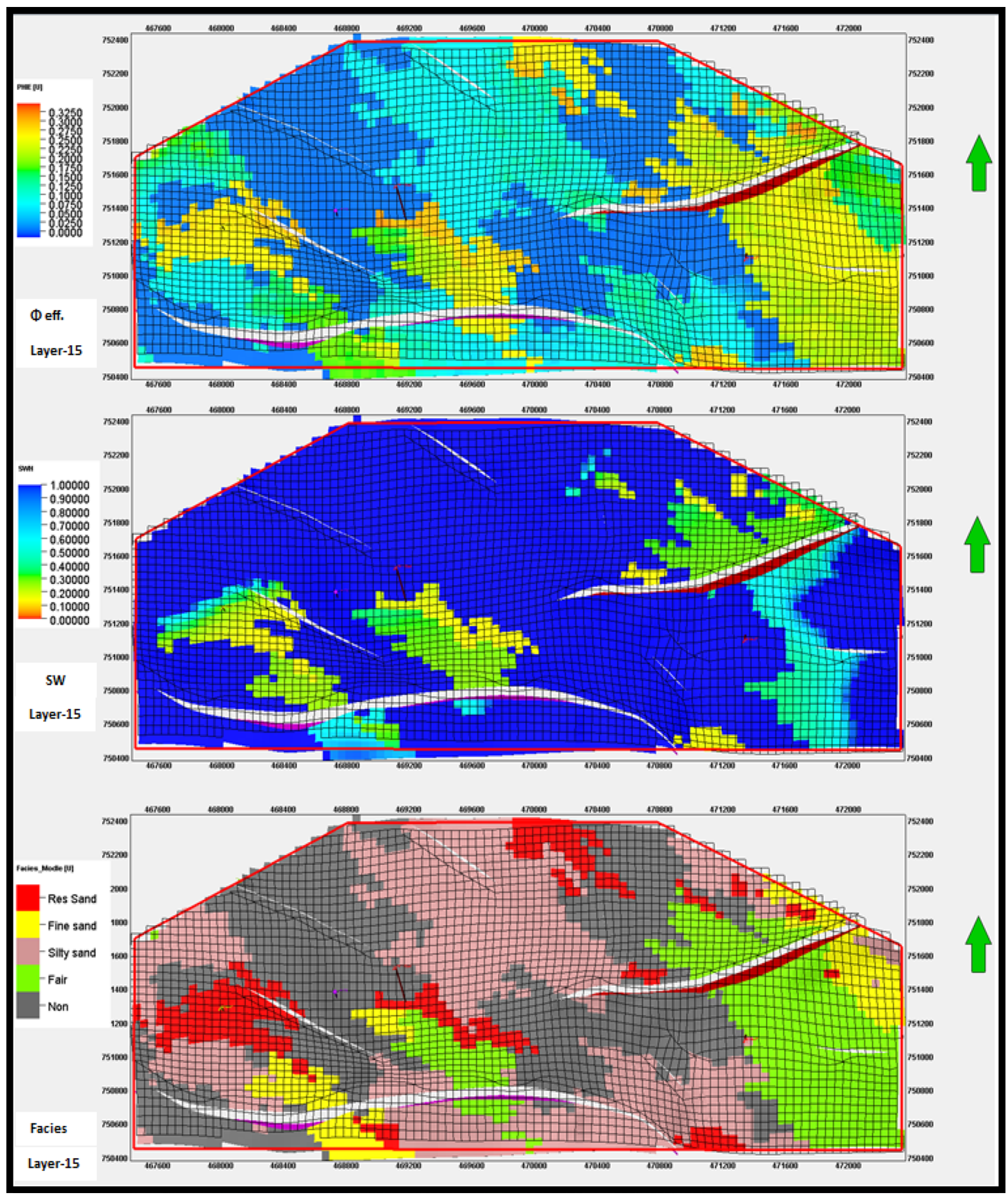

Fig. 19 Modeled effective porosity and water saturation compared to modeled Facies for a selective layer in Abu Roash "G-10"

values ranging between (max. 35\%-min. 0\%) at mouth bar sandstone facies and shale, respectively. Effective porosity tends to be controlled by facies where the mouth bar sandstone facies shows high values of effective porosity and low values of clay volume, otherwise the effective porosity of siltstone and fine sandstone decreases in layer 6 of Abu Roash "G-10" zone (Fig. 19), the distribution of effective porosity shows values layer-15 ranging between (max. 32\%-min. 0\%) at the mouth bar sandstone facies and shale, respectively. The water saturation of 
Abu Roash "G-10" zone values ranging between (max. $100 \%$-min. 20\%) the low values distributed toward the structure closures. The higher water saturation values within the main closures were due to facies change from mouth bar facies to non-reservoir fine sandstone and siltstone. Abu Roash "G-10" water saturation controlled by structure and facies, the higher water saturation values within the main closures were due to facies from mouth bar facies to inter-distributary fine sandstone and siltstone facies. Effective porosity tends to be controlled by facies, whereas the mouth bar sandstone facies show high values of effective porosity and low values of clay volume otherwise the effective porosity of siltstone and fine sandstone decreases.

\section{Lower Abu Roash G}

Three sand bodies are represented within the lower Abu Roash G the first one (G-20 zone) was subdivided into (10) layers showing periodic change between Res Sandstone, shale, Fair Sand, Silty Sand in order of decreasing, and Fine Sand in other Parts. Then in the upper layers, shale, Fine Sand, and Silty Sand and Fine Sand were dominant in most parts. These layers show a tidal creek which characterized by gradual upward increasing in Gamma ray log response which reflects a decreasing in depositional energy upward (Cant 1992). The water saturation values of Abu Roash "G-20" layer-25 ranging between (max. 100\%-min. 15\%) the low values of water saturation distributed toward the structure closures which reflect that water saturation values controlled by structure. The distribution of effective porosity at tidal creek sandstone facies and shale shows values ranging from (max. 27\%-min. 10\%). The water saturation values of $\mathrm{Abu}$ Roash "G-20" layer-31 range between (max. 100\%-min. $10 \%$ ) the low values of water saturation distributed toward the structure closures, reflecting that water saturation values controlled by structure. The distribution of effective porosity shows values ranging between (max. $32 \%-$ min. $0 \%$ ) at tidal creek sandstone facies and shale, respectively. Effective porosity is controlled by facies distribution (Fig. 20).

The second zone (G-21 zone) was subdivided into (2) layers, sowing alteration among Fair Sandstone, shale, Silty sand, and Res sand in some parts, which represented the intertidal mixed flat and mudflat of facies. The water saturation values layer-32 ranging between (max. 100\%-min. $15 \%$ ) the low values of water saturation distributed toward the structure closures that reflect that water saturation values controlled by structure. The distribution of effective porosity shows values ranging between (max. $23 \%-\min .0 \%$ ) at reservoir sandstone and siltstone, respectively. Effective porosity is controlled mainly by facies distribution.

The water saturation values layer-33 range between (max. $100 \%$-min. $16 \%$ ) the low values of water saturation distributed toward the structure closures which reflect that water saturation values controlled by structure. The distribution of effective porosity shows values ranging between (max. $22 \%-\min .0 \%$ ) at reservoir sandstone and siltstone, respectively. Effective porosity is controlled mainly by facies distribution (Fig. 21).

The third zone (G-22 zone) was subdivided into (5) layers showing facies variation from Silty Sand, Shale, Fine Sand, Fair Sandstone, and Res sand in some parts. It represents the intertidal mixed flat and mudflat of facies. This zone has not reservoir sand just bulk shale and limestone and not important to production, so assigned it as shale and take $0 \%$ porosity and $100 \%$ water saturation. The water saturation values layer-34 range between (max. $100 \%-\min .14 \%$ ) the low values of water saturation distributed toward the structure closures which reflect that water saturation values controlled by structure. The distribution of effective porosity shows values ranging between (max. 23\%-min. 0\%) at reservoir sandstone and siltstone, respectively. Effective porosity is controlled mainly by facies distribution. The water saturation values layer-38 range between (max. 100\%-min. 17\%) the low values of water saturation distributed toward the structure closures which reflect that water saturation values controlled by structure. The distribution of effective porosity shows values ranging between (max. 24\%-min. 0\%) at reservoir sandstone and siltstone, respectively. Effective porosity is controlled mainly by facies distribution (Fig. 22). The water saturation values layer- 38 range between (max. $100 \%$-min. $17 \%$ ) the low values of water saturation distributed toward the structure closures which reflect that water saturation values controlled by structure.

\section{Conclusions}

A geological model of Abu Roash G Member in Hamra oil field at the most eastern trough of the Abu Gharadig basin was constructed using the available seismic and well log data, for more understanding of the nature of the producible reservoirs in the Hamra oil field. Four horizons (Upper Bahariya, Middle Abu Roash "G", Abu Roash "C", and Abu Roash "A" members have been picked. From depth, in structure maps many normal faults were identified which 


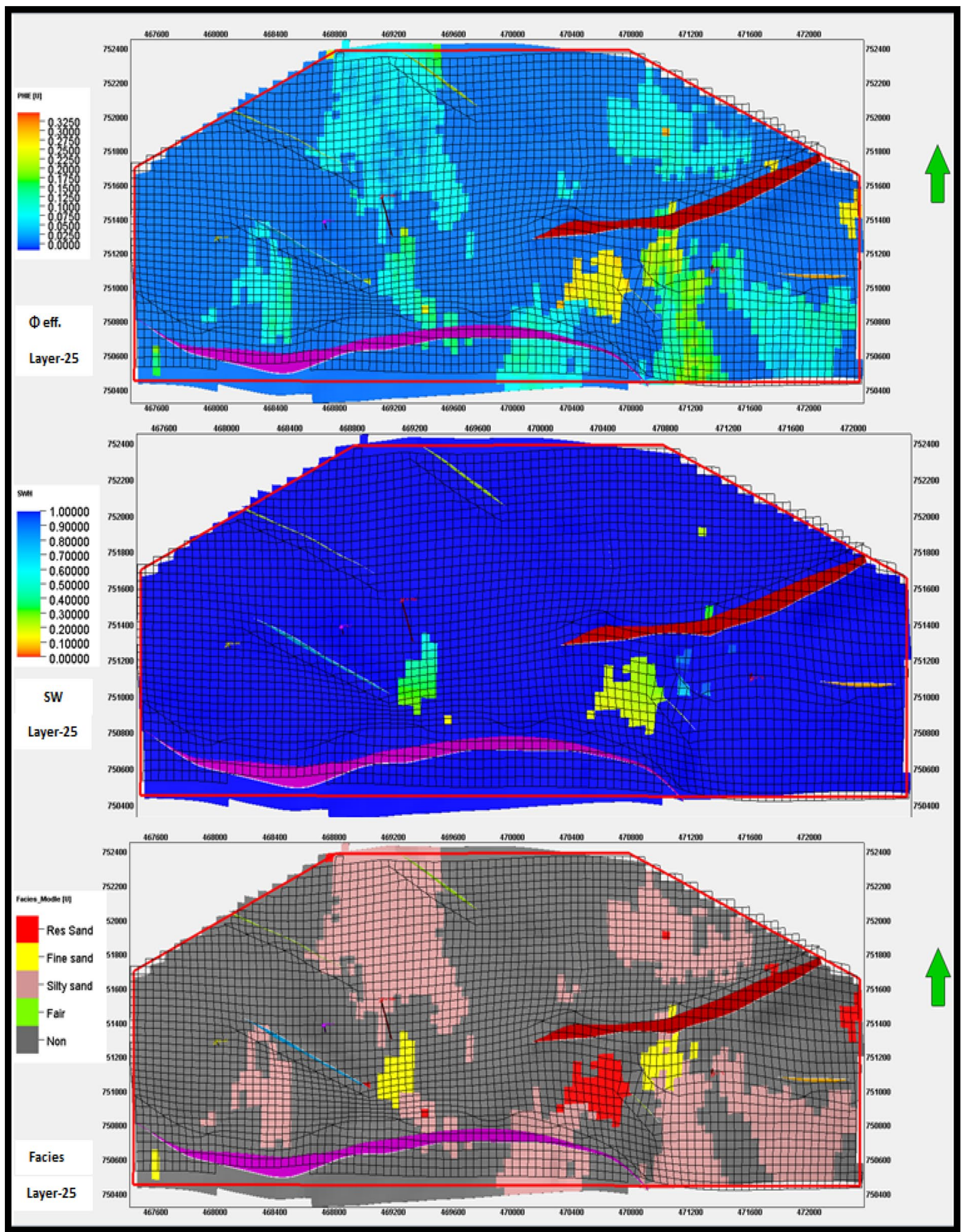

Fig. 20 Modeled effective porosity and water saturation compared to modeled Facies for a selective layer in Abu Roash "G-20" 


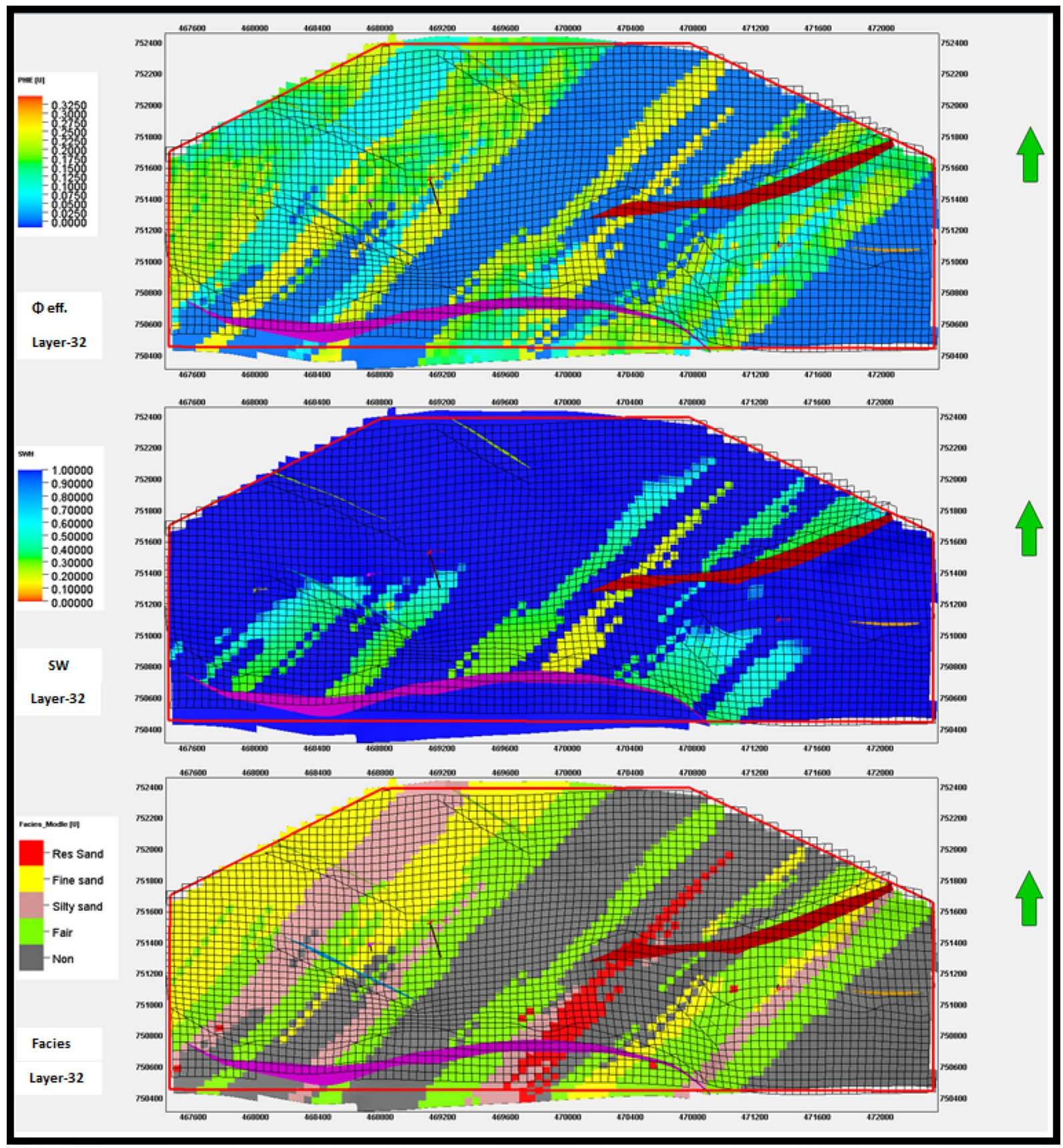

Fig. 21 Modeled effective porosity and water saturation compared to modeled Facies for a selective layer in Abu Roash "G-21"

trend to the Northwest-Southeast, East-West, and NortheastSouthwest direction. The principal structure responsible for hydrocarbon entrapment in the study area was a structural high, which corresponds to the three-way dip closure of the East-West major normal fault and the Northeast-Southwest normal fault of Hamra oil field. Although the structural study was not adequate to resolve the necessary details to identify the specific types of stratigraphic surfaces, but it was the building block for conducting the 3D reservoir model. The property modeling showed that the petrophysical parameters are controlled by the facies distribution and structure element. Middle Abu Roash "G" had a better petrophysical analysis in the central part of the deltaic environment than the other sides of the same environment, which could be tracked using seismic attributes and sedimentary structures indications from borehole image interpretation of the surrounding wells in order to improve the dynamic model and improve the behavior of the flow unit. 


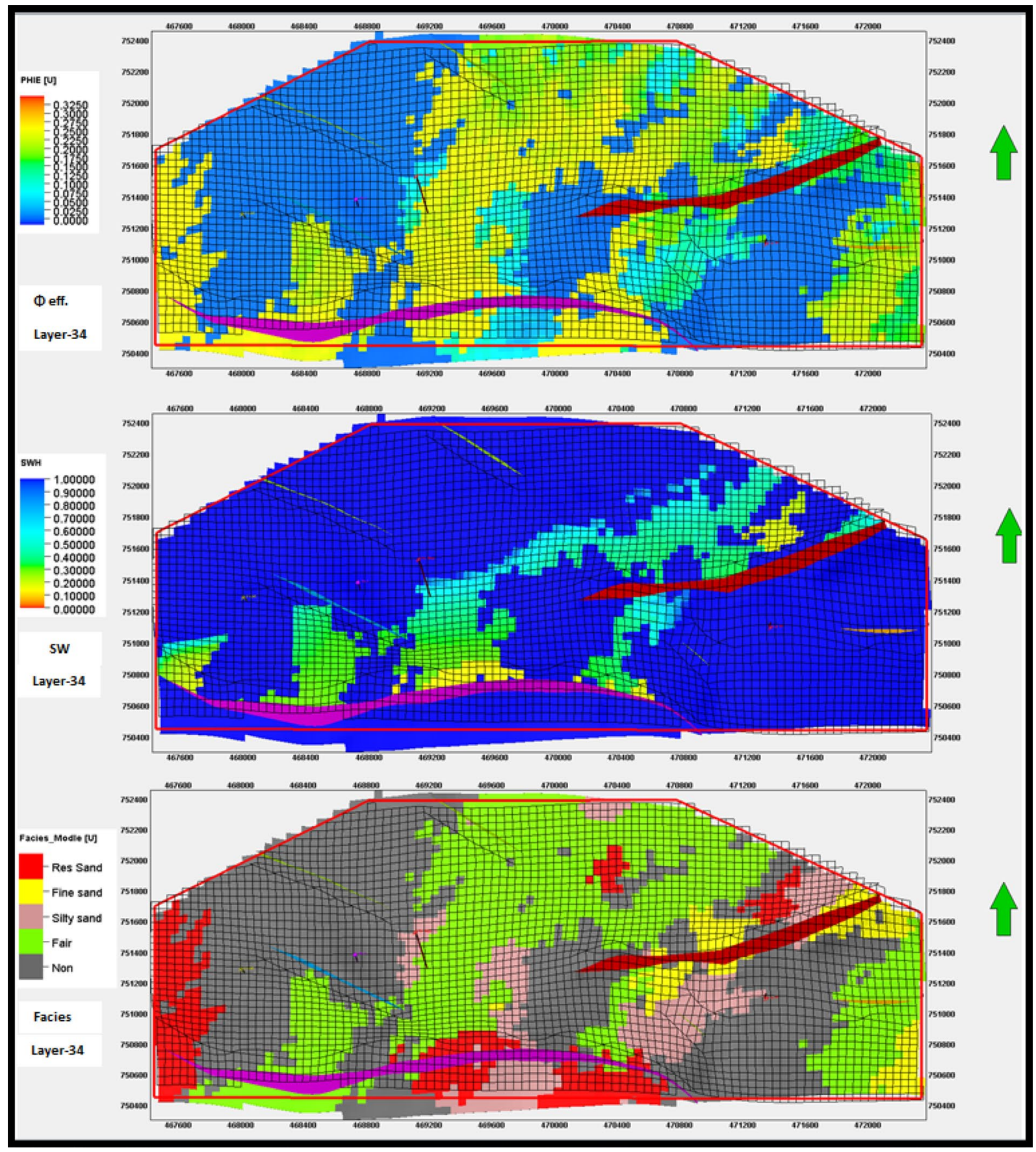

Fig. 22 Modeled effective porosity and water saturation compared to modeled Facies for a selective layer in Abu Roash "G-22"

Acknowledgements The authors wish to express their thanks and gratitude to the EGPC (The Egyptian General petroleum Corporation) and Qarun Petroleum Company for permission and release the data for this research. We also thank the reviewers and the Editor of the Journal of Petroleum Exploration and Production Technology for their careful reading of our manuscript and their many insightful comments and suggestions.

Funding There is no any sourse of funding for this work.

\section{Declarations}

Conflict of interest All authors declare that they have no conflict of interest. 
Open Access This article is licensed under a Creative Commons Attribution 4.0 International License, which permits use, sharing, adaptation, distribution and reproduction in any medium or format, as long as you give appropriate credit to the original author(s) and the source, provide a link to the Creative Commons licence, and indicate if changes were made. The images or other third party material in this article are included in the article's Creative Commons licence, unless indicated otherwise in a credit line to the material. If material is not included in the article's Creative Commons licence and your intended use is not permitted by statutory regulation or exceeds the permitted use, you will need to obtain permission directly from the copyright holder. To view a copy of this licence, visit http://creativecommons.org/licenses/by/4.0/.

\section{References}

Abd El Aziz M, Moustafa AR, Said SE (1998) Impact of basin inversion of hydrocarbon habitat in the qarun concession, Western Desert of Egypt, 14th EGPC Explor. \& Prod. Conf. 1

Abdelrheim M (2018) Seismic data analysis of Misada and Rabwa fields, East Baharya Concession, Western Desert, Egypt. M.Sc. Thesis, Azhar Univ., Cairo, Egypt

Abu El Ata ASA (1988) The relation between the local tectonics of Egypt and the plate tectonics of the surrounding regions using geophysical and geological

Abu El Naga M (1984) In Paleozoic and Mesozoic depocenters and hydrocarbon generating areas, 7th Petroleum and Exploration Seminar. Egyptian General Petroleum Corporation, Cairo northern Western Desert

Asquith G, Krygowski D (2004) Basic well log analysis, $2^{\text {nd }}$ edn. AAPG Methods in Exploration Series 16

Awad MG (1984) Habitat of oil in Abu Gharadig and Faiyum Basins, Western Desert, Egypt. AAPG Bull 68(5):564-573. https://doi. org/10.1306/AD46133B-16F7-11D7-8645000102C1865D

Bayoumi AI, Lotfy HI (1989) Modes of structural evolution of Abu Gharadig Basin, Western Desert of Egypt as deduced from seismic data. J Afr Earth Sc 9(2):273-289. https://doi.org/10.1016/ 0899-5362(89)90070-5

Bayoumi T (1996) The influence of interaction of depositional environment and synsedimentary tectonics on the development of some late Cretaceous source rocks, Abu El-Gharadig basin, Western Desert, Egypt. In: 13th petroleum exploration and production conference, Cairo, Egyptian General Petroleum Corporation

Caers J (2005) Petroleum geostatistics: SPE—An interdisciplinary approach to topic

Cant DJ (1992) Subsurface facies analysi. In: Walker RG, James NP (eds) Facies models: response to sea level change: geological association of Canada. St. John's, New-Foundland, pp 27-45

Cosentino L (2001) Static reservoir study, oil field characteristics and relevant studies, volume I. In: Exploration, production and transport. Encyclopedia of Hydrocarbon, pp 553-573

Davis JC (1986) Statistics and data analysis in geology, 2nd edn. Wiley, New York

El Diasty W (2014) Khatatba Formation as an active source rock for hydrocarbons in the northeast Abu Gharadig Basin, north Western Desert, Egypt. Arab J Geosci 8(4):1903-1920. https://doi.org/10. 1007/s12517-014-1334-x
El-Sherbiny HM (2002) Petrophysical evaluation of Abu El-Gharadig Basin; Egypt. Ph.D. Thises, Cairo Uni. Giza, Egypt

Emery D, Myers KJ (1996) Sequence stratigraphy. Blackwell, Oxford

Fathi M (2010) Seismic interpretation and petrophysical characteristics of multiple reservoir horizons in East Bahariya, Western Desert, Egypt. PhD. Thesis, Azhar Univ., Cairo, Egypt

Hendy H, Gouda S, Ghanem L (1992) Structural styles revealed by 3-D seismic data in the Abu Gharadig, Badr El-Din and Sitra lease areas, Western Desert, Egypt. In: Petroleum engineering and geosciences

Kamel I (2017) Reservoir characterization of Heba-200 oil field, North Western Desert, Egypt. M.Sc. Thesis, Suez Canal Univ., Suez, Egypt

Mahmedd M (2018) Reservoir characterization and Sequence Stratigraphic of Cretaceous age reservoir in Asala Ridge-East Bahariya Concession, Western Desert, Egypt. M.Sc. Thesis, Azhar Univ., Cairo, Egypt

Mahmoud IS, Ghazalat H, Ela Diasty W (2016) Prospect evaluation for the cretaceous reservoirs in BED-3 and Sitra, Abu Gharadig Basin, North Western Desert, Egypt. NRIAG J Astron Geophys 4(2):222-235

Meshref WM, Beleity A, Hammouda H, Kamel M (1988) Tectonic evaluation of the Abu Gharadig Basin. In: AAPG Mediterranean basins conference (1988)

Moustafa AR, Saoudi A, Moubasher A, Ibrahim IM, Molokhia H, Schwartz B (2003) Structural setting and tectonic evolution of the Bahariya

Pasley MA, Gabe Artigas N, Osama JC (2008) Depositional facies control on reservoir characteristics in the middle and lower Abu Roash "G" Sandstones, Western Desert, Egypt. Adapted from oral presentation at AAPG International Conference and Exhibition, Cape Town, South Africa, October 26-29

Pivnik D, Bedingfield J, Barker G (2007) Results from a four-year exploration and development effort in the East Bahariya Concession, Western Desert Province, Egypt; AAPG

Said R (1962) Tectonic framework of Egypt. In: Said R (eds) The geology of Egypt. Elsevier publishing company

Schlumberger (1984) Well evaluation conference, Egypt. Geology of Egypt, pp: 1-64

Schlumberger (1995) Well evaluation conference, Egypt. Schlumberger technical editing services, Chester, pp 57-68

Shahin AN, Shehab MN, Mansour HF (1986) Quantitative evaluation and timing of petroleum generation in Abu Gharadig basin, Western Desert, Egypt. In: EGPC. 6th Exploration Conference, Cairo, Egypt

Shepherd M (2009) 3-D geocellular modeling, in M. Shepherd, Oil field production geology: AAPG Memoir 91, pp 175-188

Wescott WA, Atta M, Blanchard DC, Cole RM, Georgeson ST, Miller DA, O'Hayer W, Wilson AD, Dolson JC, Sehim A (2011) Jurassic rift architecture in the northeastern western desert, Egypt; adapted from poster presentation at AAPG International Conference and Exhibition, Milan, Italy, October 23-26

Publisher's Note Springer Nature remains neutral with regard to jurisdictional claims in published maps and institutional affiliations. 